\title{
ipen
}

Autarquia Associada à Universidade de São Paulo

\section{APLICABILIDADE DE CURATIVOS A BASE DE HIDROGEL COM NANOPARTÍCULAS DE PRATA EM LESÃO POR PRESSÃO}

\section{TALITA ROCHA CARDOSO}

Dissertação apresentada como parte dos requisitos para obtenção do Grau de Mestre em Ciências na Área de Tecnologia Nuclear - Materiais

Orientador: Prof. Dr. Ademar Benevolo Lugão 


\section{Instituto de Pesquisas Energéticas e Nucleares Autarquia Associada à Universidade de São Paulo}

\section{APLICABILIDADE DE CURATIVOS A BASE DE HIDROGEL COM NANOPARTÍCULAS DE PRATA EM LESÃO POR PRESSÃO}

\section{TALITA ROCHA CARDOSO}

Dissertação apresentada como parte dos requisitos para obtenção do Grau de Mestre em Ciências na Área de Tecnologia Nuclear - Materiais

Orientador: Prof. Dr. Ademar Benevolo Lugão

Versão Original

SÃO PAULO

2017 
Ao meu Amor, por permanecer sempre ao meu lado. 


\section{AGRADECIMENTOS}

A DEUS, pela vida e a possibilidade de empreender esse caminho evolutivo, por propiciar tantas oportunidades de estudos e por colocar em meu caminho pessoas amigas e preciosas.

À MINHA FAMÍLIA, especialmente ao meu esposo, meu eterno amor. E aos meus filhos Maria Eduarda e Pedro minha força para todos os dias.

Aos MEUS PAIS E IRMÃOS que, mesmo estando a alguns quilômetros de distância, se mantiveram incansáveis em suas manifestações de apoio e carinho.

Ao ITPAC-PORTO pela confiança e incentivo a fim de promover a ciência em nosso meio

À EQUIPE DO LABORATÓRIO, em especial à Maria José, Mara, Gustavo e Jorge, pela amizade, paciência e conhecimento

Às AMIGAS Liggia, Karine e Elisangela pelo carinho e apoio sempre.

Ao MEU ORIENTADOR, um agradecimento carinhoso por todos os momentos de paciência, compreensão, competência e amizade.

A TODOS OS PARTICIPANTES desse estudo, profissionais de enfermagem do HRPN, alunos do projeto, colegas de trabalho, pela disposição em ajudar no que deles dependesse para a conclusão da pesquisa.

Aos PACIENTES E FAMILIARES DO HRPN, o meu muito obrigado. Que Deus possa abençoar cada um de vocês, que me permitiram realizar e concluir este trabalho

Enfim, a todos aqueles que de uma maneira ou de outra contribuíram para que este percurso pudesse ser concluído. 
"Dizem que a vida é para quem sabe viver, mais ninguém nasce pronto. A vida é para quem é corajoso o suficiente para se arriscar e humilde o bastante para aprender".

(Clarice Lispector) 


\title{
APLICABILIDADE DE CURATIVOS A BASE DE HIDROGEL COM NANOPARTÍCULAS DE PRATA EM LESÃO POR PRESSÃO
}

\author{
Talita Rocha Cardoso
}

\begin{abstract}
RESUMO
Cuidar de feridas é um processo dinâmico e complexo que requer atenção especial principalmente quando se refere a uma lesão crônica. A lesão por pressão (LPP) é uma ferida crônica localizada na pele ou no tecido subjacente, geralmente sobre uma proeminência óssea, resultante de pressão isolada ou pressão combinada com fricção ou cisalhamento. O objetivo foi avaliar a aplicabilidade das membranas de hidrogel com nanopartículas de prata no tratamento de lesões por pressão (LPPs) em usuários do SUS, por meio de protocolo clínico. O projeto da pesquisa foi aprovado pelo Comitê de Ética em Pesquisa da UFT/TO sob no 161/2013, e foram seguidos todos os preceitos éticos conforme Resolução 466/12 do CNS do Ministério da Saúde. Trata-se de um estudo de intervenção terapêutica, do tipo ensaio clínico não controlado, sobre a avaliação do uso da membrana de hidrogel com nanopartículas de prata (NPAg) produzida pelo Instituto de Pesquisa em Energia Nuclear (IPEN). A população do estudo foi composta por 19 pacientes, que por critérios de inclusão e exclusão foi constituída por uma amostra de 6 (seis) pacientes de ambos os gêneros, internados no Hospital de Referência de Porto Nacional, no período de janeiro de 2014 a dezembro de 2015, acometidos por lesões por pressão categoria 3, 4 e não classificável. O estudo apresentou como limitações o restrito número de pacientes por amostra, por se tratar de pesquisa clínica experimental, com um grupo investigado altamente selecionado pelos critérios de exclusão e inclusão. Os hidogéis com NPAg, produzidos pelo IPEN, mostraram-se eficazes no tratamento das LPPs, pois proporcionaram a ferida condições para a epitelização. Houve diminuição do odor, dos tecidos desvitalizados e da dor, itens estes que quando presentes retardam a cicatrização. Porém são necessários novos estudos, envolvendo estes curativos com um número maior de pacientes.
\end{abstract}

Palavras-chave: Hidrogel. Úlcera por pressão. Prata 


\title{
APPLICABILITY OF HYDROGEL BASED CURATIVES WITH SILVER NANOPARTICLES IN PRESSURE INJURY
}

\author{
Talita Rocha Cardoso
}

\begin{abstract}
Wound's care is a dynamic and complex process that requires special attention especially when referring to a chronic injury. Pressure injury (PI) is a chronic wound located on the skin or underlying tissue, usually on a prominent bone, resulting from isolated pressure or pressure combined with friction or shear. The objective of this work is to evaluate the applicability of hydrogel membranes with silver nanoparticles in the treatment of pressure lesions in SUS users, through a clinical protocol. The research project was approved by the Research Ethics Committee of UFT / TO under No. 161/2013, and all ethical precepts were followed according to Resolution 466/12 of the CNS of the Ministry of Health. It is a therapeutic intervention's study, an uncontrolled clinical trial on the evaluation of the use of hydrogel membrane with silver nanoparticles produced by the Nuclear Energy Research Institute (IPEN). The study population consisted of 19 patients, who, by inclusion and exclusion criteria, consisted of a sample of 6 (six) patients of both genders admitted to the National Reference Hospital of Porto Nacional from January 2014 to December of 2015, affected by category 3,4 and non-classifiable injuries. The study presented as limitation the restricted number of patients per sample, since it was an experimental clinical research, with a highly selected by the exclusion and inclusion criteria investigated group. The hydrogels with NPAg, produced by IPEN, were effective in the treatment of $\mathrm{PI}$, as they provided the wound conditions for epithelization. There was a decrease in odor, devitalized tissues and pain, which, when present, delays healing. However, new studies are necessary, involving these dressings with a larger number of patients.
\end{abstract}

Keywords: Hydrogel. Pressure ulcer. Silver 
1. INTRODUÇÃO

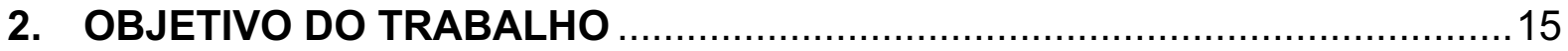

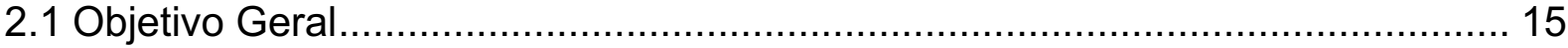

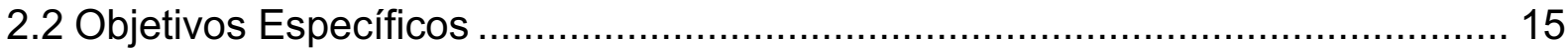

3. METODOLOGIA

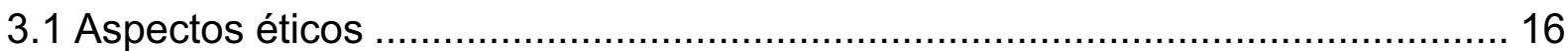

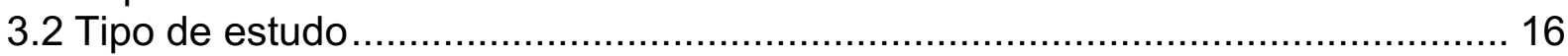

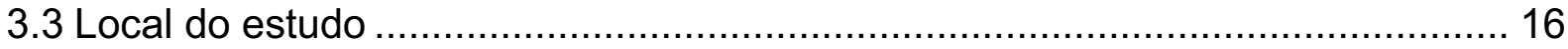

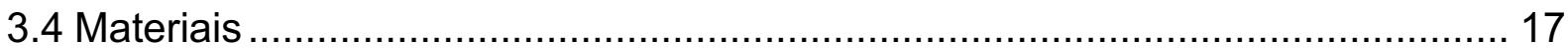

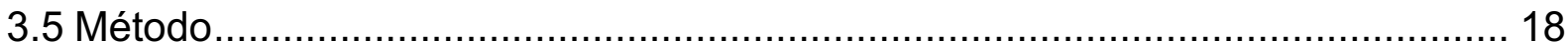

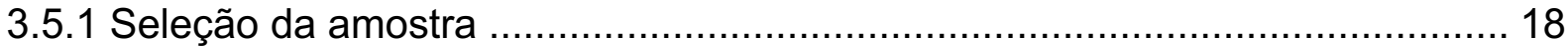

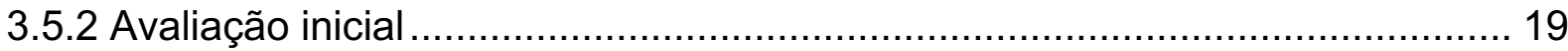

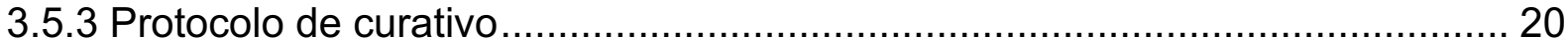

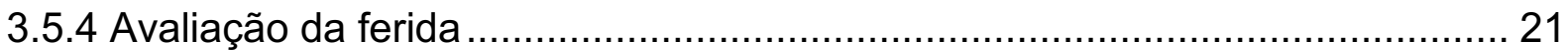

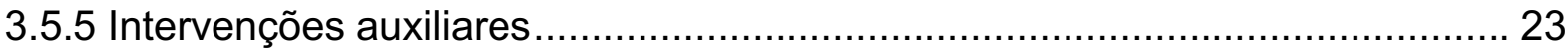

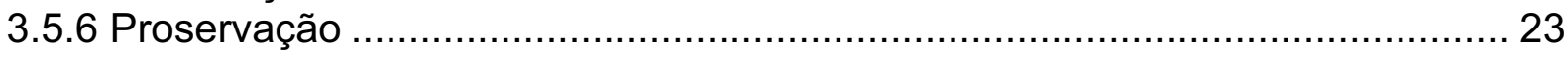

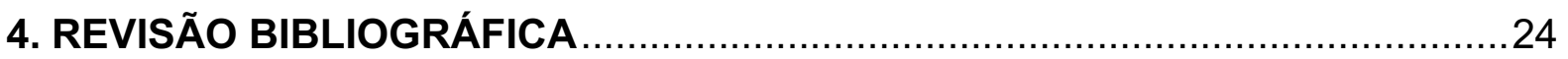

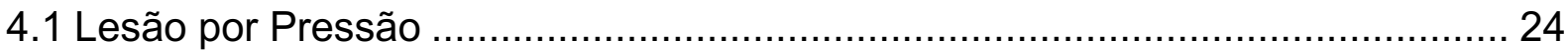

4.2 Princípios Básicos no Tratamento das Feridas ............................................. 31

4.3 Curativos de hidrogel com nanopartículas de prata ....................................... 34

4.4 Aplicação de curativos de hidrogel com nanopartículas de prata...................... 37

5. RESULTADOS

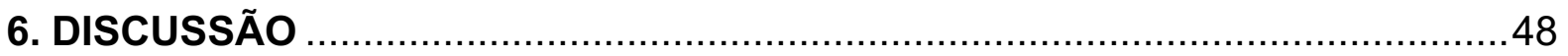

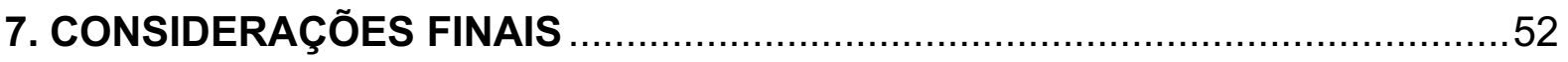

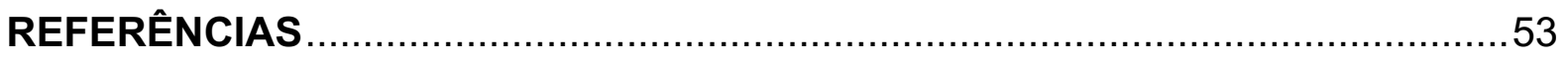

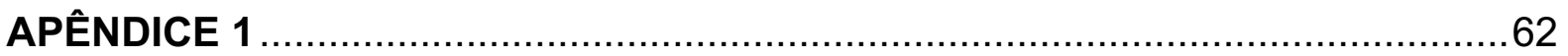

ANEXO 


\section{LISTA DE TABELAS}

Tabela 1 - Avaliação para o parâmetro de Odor

Tabela 2 - Características gerais da membrana de hidrogel com nanopartículas de prata produzida pelo IPEN/USP- 2015. .36 


\section{LISTA DE FIGURAS}

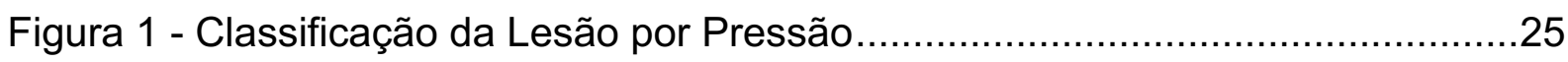

Figura 2 - Escala Númericas e Visuais Analógicas da Intensidade da dor ................29

Figura 4A - Região do Trocanter Direito, foto inicial ..........................................42

Figura 4B - Região do Trocanter Direito, após 15 dias de tratamento ......................42

Figura 5A - Região do Trocanter Esquerdo, foto inicial ..........................................43

Figura 5B - Região do Trocanter Esquerdo, após 15 dias de tratamento ...................43

Figura 6A - Região do Trocanter Direito, foto inicial ..........................................4

Figura 6B - Região do Trocanter Direito, 15 dias após tratamento ...........................44

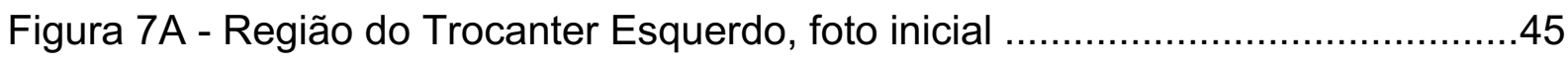

Figura 7B - Região do Trocanter Esquerdo, após 15 dias de tratamento ...................45

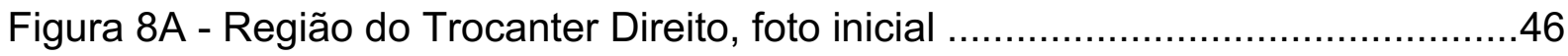

Figura 8B - Região do Trocanter Direito, após 15 dias de tratamento .......................46

Figura 9A - Região do Trocanter Direito, foto inicial ........................................47

Figura 9B - Região do Trocanter Direito, após 15 dias de tratamento .......................47 


\section{LISTA DE SIGLAS}

LPP - Lesão por Pressão

UP - Úlcera por Pressão

LPPs - Lesões por Pressão

PVP - Polivinilpirrolidona

PEG - Polietilenoglicol

NPAg - Nanopartícula de Prata

SUS - Sistema Único de Saúde

UFT - Universidade Federal do Tocantins

TO - Tocantins

CNS - Conselho Nacional de Saúde

DGES - Diretoria de Gestão da Educação na Saúde do Tocantins

SESAU - Secretária Estadual de Saúde

TCLE - Termo de Consentimento Livre e Esclarecido

IPEN - Instituto de Pesquisa

HRPN - Hospital de Referência de Porto Nacional

UCI - Unidade de Cuidados Intermediários

$\mathrm{CO}^{60}$ - Cobalto Sessenta

PUSH - Pressure Ulcer Scale for Healing

EVA - Escala Visual Analógica

A.C - Antes de Cristo

NPUAP - National Pressure Ulcer Advisory Panel

UTI - Unidade de Terapia Intensivos

$\mathrm{Ag}^{+}$- Prata iônica

$\mathbf{A g}^{0}$ - Prata Metálica

IC $_{50 \%}$ - Controle Positivo

PPM - Partes por Milhão

KGy - Kilo Gray

CMC - Carboximetilcelulose

PVA - Alcool Polivinilico

$\mathrm{AGNO}_{3}-$ Nitrato de Prata

AVE - Acidente Vascular Cerebral 



\section{INTRODUÇÃO}

O organismo humano é formado por barreiras mecânicas representadas pela integridade da pele e das mucosas, constituídas por fatores séricos e teciduais, secreção glandular e microbiota natural. A ferida representa uma ruptura na integridade destas barreiras em qualquer segmento corporal, externo ou interno (MEIRELES E SILVA, 2011).

A agressão celular pode resultar de diversos fatores, como a hipóxia, que reduz a oxigenação celular, por traumatismos, mudanças bruscas de temperatura, choque elétrico, agentes químicos, infecção, distúrbios imunológicos ou genéticos e desequilíbrio nutricional. Quaisquer que sejam as origens, causas e consequências de uma ferida, o foco principal de atenção deve ser o seu portador e todos os aspectos biopsicossociais, sempre lembrando que essa ferida necessita de intervenção terapêutica multidisciplinar para prevenir agravos, reduzir danos e favorecer a reparação tecidual (WALKER E AITKEN, 2015).

Cuidar de feridas é um processo dinâmico e complexo que requer uma atenção especial principalmente quando se refere a uma lesão crônica. Deve-se levar em consideração que as feridas crônicas evoluem rapidamente, são refratárias a diversos tipos de tratamentos e decorrem de condições predisponentes que impossibilitam a cicatrização normal (BLANES E FERRREIRA, 2004).

A lesão por pressão (LPP) é uma ferida crônica localizada na pele ou no tecido subjacente, geralmente sobre uma proeminência óssea, resultante de pressão isolada ou pressão combinada com fricção ou cisalhamento. As lesões por pressão (LPPs) destacam-se como comorbidades comuns a pacientes críticos hospitalizados, os quais apresentam maior risco de déficit tegumentar pela longa permanência no leito (NEPUAP, 2014).

O aparecimento das LPPs resulta de dois fatores etiológicos determinantes: a intensidade e a duração da pressão sobre proeminências ósseas, ocasionando isquemia e potencial necrose tecidual. A LPP é um grave problema de saúde e de ordem social e representa um grande desafio para a equipe de saúde, requerendo conhecimentos específicos para sua prevenção, diagnóstico e tratamento (GNEALPP, 2012).

A compreensão da reparação tecidual é muito importante para o entendimento da fisiopatologia e evolução das LPPs, além de orientar a escolha do 
melhor tratamento. Embora o processo de reparação tecidual seja sistêmico, para que ele seja efetivo é necessário favorecer as condições locais da lesão com tratamento tópico adequado. Neste sentido, nas últimas décadas, houve uma verdadeira revolução tecnológica baseada em pesquisas científicas, que avaliaram biomateriais e produtos diversos para o tratamento de feridas. Indústrias investem na elaboração de coberturas que têm por objetivo acelerar a reparação tecidual e minimizar o desconforto dos pacientes, facilitando a assistência e diminuindo o tempo de internação hospitalar (FÁZIO, ZITELLI E GOSLEN, 2010; BROWN, 2015).

Para serem efetivas, as coberturas precisam ser compatíveis com a fisiologia de reparação tecidual, além de atender as principais finalidades de um curativo que são: promover isolamento térmico, proteger a ferida de traumas mecânicos e da invasão bacteriana, remover tecidos necróticos e corpos estranhos, obliterar espaços mortos, absorver exsudatos e, especialmente, manter a umidade no leito da ferida. Os curativos úmidos aceleram o reparo tecidual em $50 \%$, favorecem a formação de tecido de granulação e protegem as terminações nervosas, diminuindo a dor (MATSUZAKI E KISHI, 2015).

As membranas de hidrogel com nanopartículas de prata reúnem a maior parte das características de uma cobertura efetiva e configuram uma boa indicação para feridas crônicas como as LPPs. São definidas como uma blenda polimérica de poli(N-vinil-2pirrolidona) (PVP), polietilenoglicol (PEG) e ágar, formando uma rede tridimensional composta de polímeros reticulados por irradiação ionizante. $O$ uso da radiação na formação de hidrogéis possibilita a reticulação e esterilização simultânea, permitindo a síntese de um produto não contaminado com resíduos tóxicos de iniciadores, além de ser uma tecnologia que permite simplificação do processo de produção e redução de custos (SUNARTI, 2015; LUGÃO, 2001).

As LPPs podem ser rapidamente contaminadas e infectadas por microrganismos, tais como bactérias multi-resistentes ou fungos. A introdução de prata como agente antimicrobiano para o tratamento de feridas tem sido amplamente eficaz, contribuindo para a cura da lesão. A membrana de hidrogel com nanopartículas de prata (NPAg) é largamente utilizada no tratamento de feridas crônicas, somando os benefícios do hidrogel com a ação antimicrobiana da prata. Essa cobertura objetiva reduzir a carga microbiana da ferida para diminuir sua interferência na reparação tecidual (BOONKAW et al., 2013; OYARZUN-AMPUERO et al., 2015). 
A maioria das coberturas de hidrogel é importada para o Brasil, o que torna os custos do seu uso oneroso para um elevado número de pacientes portadores desse tipo de lesão. Estima-se que, o custo do tratamento de cada paciente com LPP seja de U\$ 2.000 a U\$ 30.000, por isso o desenvolvimento de curativos a partir de materiais e tecnologias disponíveis em universidades, constituem uma excelente alternativa para o tratamento detes pacientes no SUS (Sistema Único de Saúde) (LIMA E GUERRA, 2011; PALFREYMAN E STONE, 2015). 


\section{OBJETIVO DO TRABALHO}

\subsection{OBJETIVO GERAL}

- Avaliar a aplicabilidade das membranas de hidrogel com nanopartículas de prata no tratamento de lesões por pressão em usuários do SUS, por meio de protocolo clínico.

\subsection{OBJETIVOS ESPECÍFICOS}

- Avaliar macroscopicamente a reparação tecidual das lesões por pressão, pelos parâmetros de tamanho, odor, dor, quantidade de secreção e tecido desvitalizado.

- Identificar a microbiota predominante presentes nas lesões por pressão, através de cultura.

- Avaliar o potencial antimicrobiano das membranas de hidrogel com nanopartículas de prata, a partir da reparação tecidual, melhora do odor e da secreção nas feridas. 


\section{METODOLOGIA}

\subsection{ASPECTOS ÉTICOS}

O projeto da pesquisa foi aprovado pelo Comitê de Ética em Pesquisa da UFT/TO sob $n^{\circ}$ 161/2013 (ANEXO A), e foram seguidos todos os preceitos éticos conforme Resolução 466/12 do CNS do Ministério da Saúde. Este projeto também foi enviado à Diretoria de Gestão da Educação na Saúde do Tocantins (DGES), atendendo à portaria SESAU $n^{\circ} 762$ de $1^{\circ}$ de novembro de 2011, que regulamenta 0 fluxo de pesquisa nas unidades sob gestão da Secretária Estadual da Saúde.

Esta pesquisa não implicou em maleficência, nem qualquer risco à saúde dos participantes, que tiveram total privacidade em relação à sua integridade física e moral. O paciente foi considerado voluntário da pesquisa somente após ele próprio e/ou responsável ler e compreender os procedimentos técnicos do anonimato, objetivo, vantagens e desvantagens do estudo e assinar o Termo de Consentimento Livre e Esclarecido (TCLE). Para preservar as identidades dos sujeitos da pesquisa foram adotados números para cada paciente que optou em participar do estudo de forma voluntária.

\subsection{TIPO DE ESTUDO}

Trata-se de um estudo de intervenção terapêutica, do tipo ensaio clínico não controlado sobre a avaliação do uso da membrana de hidrogel com nanopartículas de prata produzido pelo Instituto de Pesquisa em Energia Nuclear (IPEN) no tratamento de lesões por pressão, categoria III e IV e não classificável (NEPUAP, 2014).

\subsection{LOCAL DO ESTUDO}

O estudo foi realizado no Hospital de Referência de Porto Nacional (HRPN), nos setores de clínica geriátrica e unidade de cuidados intermediários (UCl). O HRPN se localiza na cidade de Porto Nacional, estado do Tocantins, apresenta 90 leitos, e é considerado um hospital de média complexidade, sendo 
referência em saúde para 16 municípios circunvizinhos.

\subsection{MATERIAIS}

Para o desenvolvimento da pesquisa foram utilizados os materiais conforme descrição abaixo:

a) Paquímetro digital;

b) Régua milimetrada;

c) Instrumental para curativo (Pinça Kelly, Pinça anatômica, Pinça Adison);

d) Membranas de Hidrogel com nanopartícula de prata (IPEN USP);

e) Gazes estéreis

f) Coxins estéreis;

g) Ataduras estéreis;

h) Luvas estéreis;

i) Luvas de procedimento;

j) Solução fisiológica estéril de $\mathrm{NaCl}$ a $0,9 \%$;

k) Máscara descartável;

l) Lâmina de bisturi $n^{\circ} 15$ e $n^{\circ} 24$;

m) Seringa descartável de insulina e de $20 \mathrm{~mL}$;

n) Esparadrapo e micropore;

o) Avental descartável;

p) Touca descartável;

q) Agulha descartável $25 \times 8 \mathrm{~mm} 21 \mathrm{G}$;

r) Esfigmomanômetro digital;

s) Oxímetro de pulso;

t) Termômetro.

As membranas de hidrogel, que representam 0 material de experimentação, foram desenvolvidas pelo IPEN por meio de um processo que permite considerável redução de custos. Esse processo se baseia na reticulação do PVP com simultânea esterilização da membrana, pela irradiação gama por fonte de $\mathrm{CO}^{60}$. As membranas de hidrogel foram fornecidas ao pesquisador pelo IPEN sem custo.

A membrana de hidrogel com nanopartículas de prata produzidas pelo IPEN 
(USP) foi sintetizada com $22 \mathrm{ppm}$ de prata, seladas e reticuladas em irradiador de cobalto-60, do tipo multipropósito, com raios gama provenientes de fonte de ${ }^{60} \mathrm{CO}$ com dose de $25 \mathrm{KGy}$. O quadro abaixo apresenta a descrição das características gerais dessa cobertura.

Tabela 2 - Características gerais da membrana de hidrogel com nanopartículas de prata produzida pelo IPEN/USP- 2015

Gel transparente, incolor, composto por: água, Composição polivinilpirrolidona (PVP), PEG, Agar, CMC, 22 ppm de nanopartículas de prata (NPAg)

\begin{tabular}{|c|c|}
\hline $\begin{array}{l}\text { Mecanismo de } \\
\text { ação }\end{array}$ & $\begin{array}{l}\text { Amolece e remove o tecido desvitalizado através de } \\
\text { desbridamento autolítico e possui ação bactericida } € \\
\text { bacteriostática. }\end{array}$ \\
\hline Tipos de feridas & $\begin{array}{l}\text { Feridas com crostas, fibrinas, tecidos desvitalizados } \\
\text { necrosados e tecidos de granulação. }\end{array}$ \\
\hline Contra-indicação & $\begin{array}{l}\text { Feridas cicatrizando por primeira intenção e de } \\
\text { abundante exsudato. }\end{array}$ \\
\hline Modo de usar & $\begin{array}{l}\text { Lavar o leito da ferida com SF } 0,9 \% \text {. } \\
\text { Secar as bordas } \\
\text { Aplicar a membrana sobre a ferida de forma asséptica } \\
\text { Ocluir a ferida com cobertura secundaria. }\end{array}$ \\
\hline $\begin{array}{c}\text { Periodicidad } \\
\text { troca }\end{array}$ & Por até 72 horas \\
\hline
\end{tabular}

Fonte: Centro de Química e Meio Ambiente - IPEN

\subsection{MÉTODO}

\subsubsection{Seleção da amostra}

A população do estudo foi composta por 19 pacientes, que por critérios de inclusão e exclusão foi constituida por uma amostra de seis (6) pacientes de ambos os gêneros, internados no Hospital de Referência de Porto Nacional, no período de janeiro de 2014 a dezembro de 2015, acometidos por lesões por pressão categoria III e IV e não classificável (NEPUAP, 2016) com presença de tecido desvitalizado, localizadas em região do trocanter esquerdo ou direito. Para a seleção dos voluntários do estudo, foram adotados os seguintes critérios: 
Os critérios de inclusão:

- Idade acima de 18 anos;

- Internação no setor da clínica geriátrica e unidade de cuidados intermediários no período de janeiro de 2014 a dezembro de 2015.

- Apresentar lesão por pressão em região trocantérica direita ou esquerda, em estágio III, IV ou não classificáveis (NEPUAP 2016);

- Presença de tecido desvitalizado no leito da ferida;

- Presença ou não de infecção;

- Nenhuma contra-indicação para o uso dos medicamentos propostos no estudo.

Os critérios de exclusão:

- Histórico de hipersensibilidade aos fármacos em estudo (reação normal ao fármaco ou idiossincrásica);

- A pedido do paciente ou familiar;

- Presença de lesões por pressão em outras regiões anatômicas, que não seja a trocantérica;

- Internação em outro setor do hospital;

- Participação de qualquer estudo clínico similar nas seis semanas que antecederem ao estudo.

\subsubsection{Avaliação inicial}

Na primeira sessão, após o voluntário e/ou responsável aceitar participar da pesquisa mediante assinatura do TCLE (APÊNDICE 1), foi realizada uma anamnese e mensuração dos sinais vitais (pressão arterial, frequência cardíaca, frequência respiratória, saturação parcial de oxigênio e temperatura). Os valores encontrados foram considerados basais e esta avaliação foi refeita a cada sete (7) dias durante os 15 (quinze) dias de experimentação para cada paciente.

A pressão arterial e frequência cardíaca foram avaliadas através de um esfigmomanômetro digital calibrado e com selo de aprovação pela Sociedade Brasileira de Hipertensão. A saturação parcial de oxigênio foi avaliada através de oxímetro de pulso calibrado. A frequência respiratória foi avaliada com auxílio de relógio de pulso e a temperatura através do termômetro digital. 
Foram registradas em formulário próprio de avaliação os exames laboratoriais de sangue (hemograma completo, uréia, creatinina, albumina total e glicemia em jejum); a avaliação de sinais vitais e as medicações prescritas.

Uma avaliação incial da ferida também foi realizada. A área das lesões foi medida através de paquímetro digital e régua milimetrada. As medidas foram anotadas em centímetros, considerando largura versus comprimento e profundidade. Também foi registrada a quantidade de exsudato, a aparência do leito da ferida e o odor. Imagens fotográficas do aspecto inicial das lesões foram tomadas para posterior análise e comparação da evolução do tratamento.

\subsubsection{Protocolo de curativo}

Todos os curativos e avaliações da ferida foram realizados pela mesma operadora (pesquisadora), seguindo rigorosamente protocolo descrito:

a) Abordar o paciente explicando sobre o procedimento;

b) Higienizar as mãos, conforme protocolo do Ministério da Saúde (2009), colocar a máscara e retirar o curativo anterior com luva de procedimento, avaliando quantidade e aspecto de exsudado, dor durante a retirada e maceração nas bordas da ferida;

c) Abrir o pacote de curativo e calçar a luva estéril;

d) Lavar em jatos o leito da ferida utilizando solução salina 0,9\% em seringas de $20 \mathrm{ml}$ e agulha de tamanho $25 \mathrm{~mm} \times 0,8 \mathrm{~mm}$, gerando uma pressão de 12,5 psi (libras/polegadas) (MARTINS, 2012);

e) Limpar as bordas com gazes estéreis embebidas com a solução salina e realizar desbridamento mecânico na fibrina, se presente, através da utilização de pinças, com o objetivo de retirar tecidos inviáveis;

f) Retirar as luvas e registrar a ferida através de imagem fotográfica;

g) Calçar a luva estéril novamente e terminar o procedimento;

h) Cobrir a lesão com curativo primário, seguida por um curativo secundário (seco) formado por cinco gazes secas empilhadas;

Por ocasião do estudo as coberturas primárias utilizadas foram membranas de hidrogel com nanopartículas de prata.

As trocas das membranas de hidrogel com nanopartícula de prata, foram 
realizadas conforme protocolo acima, considerando a umidade, drenagem de secreção e sujidade.

\subsubsection{Avaliação da ferida}

Foi considerado um tempo de experimentação de duas semanas para padronização da avaliação dos pacientes incluídos na pesquisa. Todos os voluntários receberam acompanhamento clínico diariamente pela equipe técnica do HRPN durante o período de experimentação. Os pacientes que continuaram internados após período de estudo, receberam acompanhamento clínico e curativo de acordo com a rotina do HRPN até sua alta hospitalar.

Foram anotados no instrumento de coleta da pesquisa, o lado do trocanter afetado e a mensuração da ferida, juntamente com a classificação de estágio da LPP. As lesões foram medidas em comprimento e largura por régua milimetrada e paquímetro digital, no primeiro dia do curativo e a cada sete dias, durante duas semanas. Para avaliar a profundidade da lesão foi utilizada uma seringa estéril. Introduziu-se a seringa na cavidade da ferida para marcar a profundidade verificando seu tamanho com uma régua milimetrada (DEALEY, 2008).

O perímetro da ferida foi traçado pela técnica de decalque, que consistiu em desenhar o formato da ferida utilizando acetato ou folha de plástico transparente, caneta retroprojetora e papel quadriculado em centímetros, de forma a identificar o tamanho preciso da lesão. Colocou-se uma folha estéril transparente em cima da ferida e outra sobreposta, e com a caneta retroprojetora foi feito uma cópia do formato da lesão, seguindo as bordas. A folha que ficou em contato direto com a ferida foi desprezada, e a outra folha foi anexada no prontuário do paciente, para possível comparação (OLIVEIRA, CASTRO, ANDRADE, 2005).

Para avaliar o parâmetro odor, utilizou-se a escala TELER (Treatment Evaluation by Le Roux Method), um instrumento de medição validado em feridas malignas que mede, em concordância com outros sintomas, a presença do odor em seis níveis, numa escala decrescente na intensidade (BROWNE et al., 2004). 
Tabela 1 - Avaliação para o parâmetro de Odor

\begin{tabular}{c|l}
\hline SCORE & ODOR \\
\hline 5 & Sem odor \\
4 & Odor é detectado na remoção da cobertura \\
3 & Odor é evidente na exposição da cobertura \\
2 & Odor é evidente a uma distancia de um braço do \\
1 & paciente \\
\hline Fonte: Escala TELER (Treatment Evaluation by Le Roux Method)
\end{tabular}

A escala Pressure Ulcer Scale for Healing (PUSH) classifica a avaliação do exsudato como: nenhum, escasso, moderado e abundante. A fim de padronizar a quantificação do exsudato a pesquisadora definiu a quantidade de gazes que foram utilizadas na cobertura das lesões. Todos os curativos, independentemente da área de lesão, receberam a mesma quantidade de cobertura secundária, conforme o tipo de curativo, e ficou definido: nenhum exsudato (umidade de exsudato em $<50 \%$ das gazes com uma troca de curativo em 24 horas ); escasso (umidade de exsudato maior ou igual a 50\% das gazes com uma troca de curativo em 24 horas); moderado (umidade de exsudato nas gazes que exija duas trocas em 24 horas para manter a integridade dos tecidos peri lesão, evitando a maceração) e abundante (umidade de exsudato nas gazes que exija três ou mais trocas de curativos em 24 horas para manter a integridade dos tecidos peri lesional, evitando a maceração) (BORGES,2012).

Avaliou-se a dor durante o procedimento de retirada do curativo experimental (hidrogel) pelo registro na Escala Visual Analógica (EVA), numerada de "zero" a 10 (dez), onde "zero" indica ausência de dor e 10 (dez) dor intensa (BLANES E FERREIRA, 2014). O paciente foi orientado a registrar na escala através de um traço, a intensidade dolorosa percebida durante a retirada do curativo.

Imagens fotográficas da ferida foram tomadas de forma padronizada por câmera digital, na avaliação inicial e a cada sete dias, por um período de duas semanas (BLANES, 2013). A imagem fotográfica fornece uma amostra clara da aparência da ferida e sugere o tamanho da mesma, servindo como parâmetro para avaliações posteriores. O objetivo da imagem foi explicado aos pacientes e familiares, que autorizaram as fotos por meio de assinatura do termo de autorização de imagem. 


\subsubsection{Intervenções auxiliares}

Durante o período de avaliação, no caso de não observação de melhora da lesão por pressão, mediante o emprego dos curativos utilizados, era solicitado ao médico cirurgião da equipe de curativo, que procedesse um debridamento instrumental ou cirúrgico para a retirada de tecido desvitalizado. Neste caso, a amostra era descartada e recebia atenção da equipe para continuidade dos cuidados até sua alta.

\subsubsection{Proservação}

Após a alta hospitalar, manteve-se contato com os pacientes em retornos agendados no ambulatório de curativos do HRPN, para avaliação da lesão até seu total fechamento. 


\section{REVISÃO BIBLIOGRÁFICA}

\subsection{LESÃO POR PRESSÃO}

\footnotetext{
Lesão por pressão (LPP) é definida como uma lesão crônica localizada na pele ou no tecido subjacente, geralmente sobre uma proeminência óssea, resultante de pressão isolada ou pressão combinada com fricção ou cisalhamento (NEPUAP, 2016).
}

Evidências associam estas lesões aos primórdios da história da humanidade. Os primeiros achados datam de 2050-1800 a.C. em corpos de múmias egípcias e a sua primeira descrição consta em escritos científicos de 1593. Frabicius Hildanus descreveu pela primeira vez as características e defendeu entre as causas possíveis, naturais e sobrenaturais, a interrupção no fornecimento de sangue e nutrientes à pele (SALES, BORGES E DONOSO, 2010).

Vários são os termos utilizados para definir a LPP; os mais comuns são "escara" e "úlcera de decúbito". Contudo, o termo "escara" refere-se ao tecido necrosado ou crosta enegrecida que, quando presente, impossibilita a classificação da LPP, e cuja remoção é necessária. O termo decúbito, que significa "ficar deitado", também não é adequado para designar esse tipo de ferida, pois a LPP abrange as lesões isquêmicas adquiridas em outras posições como, por exemplo, na posição sentada (WOCN, 2003).

A terminologia adequada, consagrada e mais utilizada mundialmente, conforme a proposta das diretrizes internacionais, é lesão por pressão, uma vez que a pressão é o fator etiológico mais importante na gênese dessas lesões (WALKER E AITKEN, 2015).

As lesões por pressão (LPPs) podem surgir em poucas horas, quando o suprimento sanguíneo das camadas cutâneas é reduzido pelo aumento da pressão externa sobre o leito capilar. Esta interrupção do fluxo sanguíneo interfere na oxigenação e nutrição dos tecidos, ocasionando, edema, hipóxia, acidose tissular e necrose celular (BLANES E FERREIRA, 2014).

A incidência e prevalência de lesões por pressão no Brasil são semelhantes às relatadas na literatura mundial. Estima-se uma incidência de 39,8\%, podendo alcançar $41 \%$ em pacientes com alto risco. Estudos do perfil epidemiológico de pacientes com lesão por pressão verificou maior prevalência no sexo masculino, 
vítimas de lesão medular, com lesões avançadas, localizadas predominantemente na cintura pélvica (COSTA et al., 2005).

De acordo com o National Pressure Ulcer Advisory Panel (NPUAP), a prevalência de lesão por pressão nos hospitais dos Estados Unidos varia de $3 \%$ a $14 \%$, aumentando para $15 \%$ a $25 \%$ nos casos em que os pacientes se encontram em repouso absoluto (ROGENSKI e SANTOS, 2005). Estudos na literatura demonstram que a incidência de lesão por pressão em pacientes hospitalizados em UTI, no Brasil, varia de $10,6 \%$ a $55 \%$. A incidência de úlcera de pressão em pacientes neuropatas varia entre $7,5 \%$ e 31,7\% (FERNANDES, TORRES, 2008). E, no Hospital Universitário da Universidade de São Paulo, constatou-se que a incidência de lesão por pressão na clínica cirúrgica corresponde a 36,5\% (DECCINI et al., 2009).

Em estágios avançados, o tratamento da lesão por pressão pode ser demorado e de alto custo, e em alguns casos é necessária intervenção cirúrgica. No Brasil, não existem dados precisos na literatura a respeito dos custos gerados pelas lesões por pressão para o sistema de saúde. Contudo, estudos internacionais demonstram que cada lesão pode custar de 2 mil a 30 mil dólares, podendo, de acordo com o estágio, chegar a 1,3 bilhão de dólares por ano (PALFREYMAN E STONE, 2015).

Um aspecto importante no diagnóstico e tratamento das lesões por pressão é a característica evolutiva das mesmas. A lesão em estágio inicial com manutenção dos fatores que a originaram, muito provavelmente apresentará progressão para os estágios mais avançados. Por isso, as lesões por pressão são classificadas segundo os tecidos acometidos com relação direta a profundidade da lesão (COLEMAN et al., 2014).

A National Pressure Ulcer Advisory Panel (NEPUAP) havia definido uma classificação com quatro estágios de lesões por pressão e acrescentou duas novas categorias a partir de 2009: lesão suspeita de tecidos profundos, e não classificável (NEPUAP, 2014).

Assim, a classificação atual segundo a gravidade é a seguinte: Estágio/categoria 1: pele intacta com rubor não branqueável em uma área localizada; Estágio/categoria 2: perda da espessura parcial da derme, que se apresenta como uma ferida superficial com leito vermelho; Estágio/categoria 3: perda total da espessura da pele, pode estar visível o tecido adiposo subcutâneo; 
Estágio/ categoria 4: perda total dos tecidos com exposição óssea, dos tendões ou músculos e frequentemente são cavitárias; Lesão suspeita de tecidos profundos: área vermelho escura ou purpúra localizada em pele intacta e pálida, ou flictena hemática; Não classificável: perda de espessura total da pele, em que o leito encontra-se recoberto por necrose.
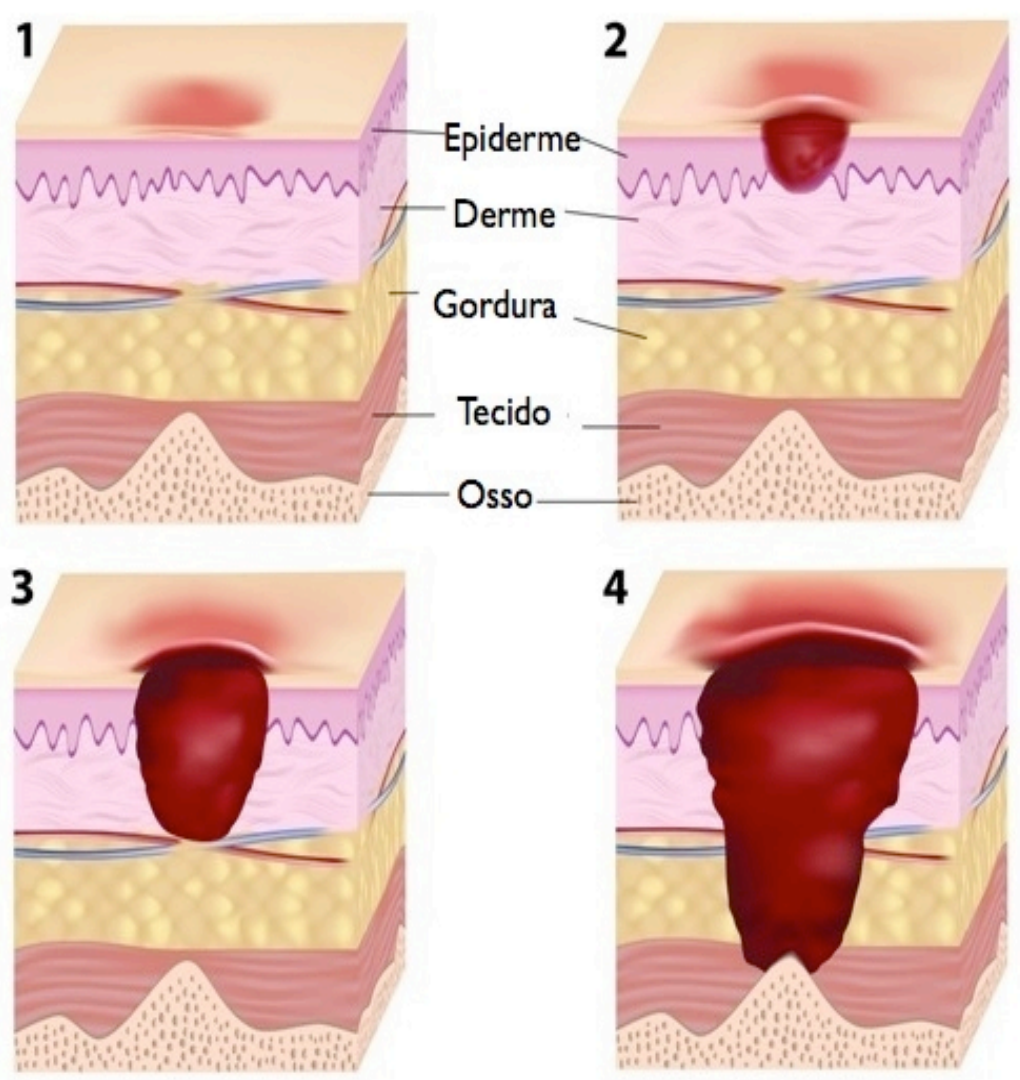

4
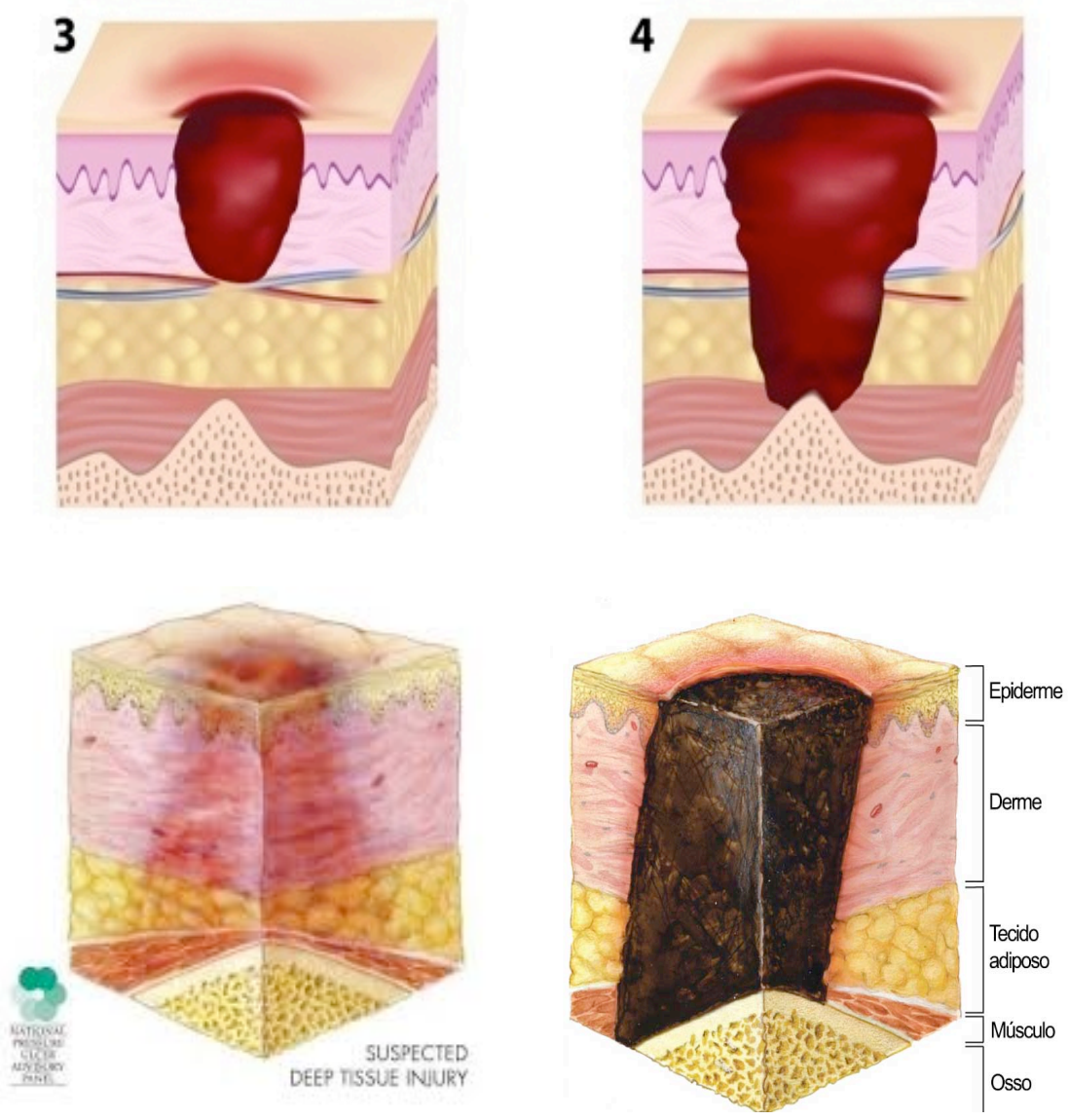

Suspeita de lesão profunda Lesão não classificável

Figura 1 - Classificação de lesão por pressão

Fonte: Segundo (NEPUAP, 2016)

As lesões do estágio 2, 3 e 4 são invariavelmente colonizadas por bactérias e 
na maior parte dos casos exige uma limpeza adequada e debridamento para evitar a instalação de uma infecção clínica (FRANCO E GONÇALVES, 2008). O processo infeccioso nas feridas ocorre a partir da invasão e da multiplicação de microrganismos no tecido vivo, que pode ser inaparente ou apresentar uma injúria celular local, devido a liberação de toxinas, replicação intracelular, ou resposta antigênica (FALABELLA, 2006).

A identificação dos microrganismos colonizadores das lesões por pressão corresponde a uma etapa importante do tratamento, pois irá determinar o tipo de cobertura local ou a terapêutica prescrita. A cultura por swab e a biópsia com cultura quantitativa são métodos de identificação mais utilizados. A cultura por swab é um método de fácil realização com taxa de acerto do swab entre $65 \%$ a 98\%, entretanto, não é aconselhado em feridas crônicas, porque o resultado pode representar apenas a contaminação superficial da lesão. A biópsia com cultura quantitativa, quando realizada corretamente, tem uma taxa de $90 \%$ a $100 \%$ e constitui uma ferramenta fidedigna para comprovar o grau de infecção (PAGGIARO, TEIXEIRA E FERREIRA, 2010).

A pele, uma vez lesionada por meio de processos crônicos patogênicos pode ser contaminada por bactérias provenientes da pele. Dentre as espécies, encontram-se regularmente, Staphylococcus aureus, Pseudomonas aeruginosa, Proteus vulgaris, Proteus mirabilis, Escherichia coli, Klebsiella p., Citrobacter sp., Streptococcus hemolíticos dos grupos A, B, C e G, diferentes espécies de anaeróbios e raramente, fungos, como Cândida albicans (MARTINS, 2012).

Para controlar a colonização bacteriana os antissépticos e antibióticos tópicos eram aceitos como melhores opções de tratamento. No entanto, as coberturas com substâncias microbicidas incorporadas apresentam-se como boas alternativas para a redução da carga bacteriana nas feridas, contribuindo para a reparação tecidual (SARABAHI, 2012).

Evidências sugerem que a presença de colonização bactériana na ferida interfere em várias etapas do processo de cicatrização, sobretudo em feridas crônicas como as LPP. A infecção prolonga a fase inflamatória e interfere com a epitelização, contração e deposição de colágeno (ROWLEY-CONWY, 2010).

As LPPs apresentam muitas formas de tecidos, alguns significam a melhora da lesão e outros que provocam a piora da lesão. Por isso o conhecimento detalhado do processo de reparo tecidual é muito importante para o sucesso de 
qualquer tratamento. O exame periódico da ferida com registro de sua evolução deve fazer parte da rotina de conduta da equipe de saúde (BRYANT E NIX, 2007).

A epitelização é a regeneração da epiderme através de uma superfície da ferida. O processo de epitelização começa quando queratinócitos basais dos apêndices dérmicos migram através do local da ferida e proliferam-se nas bordas, formando um tecido de cobertura liso, fino e rosado (ESTEBAN-VIVES et al., 2015).

O tecido de granulação é um passo intermediário na cicatrização de feridas de espessura total. Quando saudável é vermelho, brilhante e granular, sendo constituído por novos capilares, fibroblastos e colágeno. Ele é uma fase importante para promover a cicatrização das bordas de uma LPP em toda a espessura. 0 tecido de granulação macio e frágil pode ser danificado por curativos secos ou aderentes, e/ou por irrigação de alta intensidade nas feridas. Quando uma pressão é aplicada, o fluxo sanguíneo é prejudicado, o tecido escurece, e a infecção pode destruir o tecido de granulação (BROWN, 2015).

Já o tecido fibrinoso é um subproduto inflamatório e não um tecido físico. É resultado da coagulação de proteínas de soro e de matriz produzidos por feridas infectadas, geralmente descrito como um tipo de tecido necrótico. Portanto, o tecido fibrinoso é um indicador de inflamação da ferida. A cicatrização não começará até que a fibrina seja removida e a causa do processo inflamatório seja controlada (BOSANQUET et al., 2015).

O tecido fibrinoso pode ter cores diferentes, dependendo da sua composição bacteriana. Fibrina branca indica colonização bacteriana escassa, amarela ou verde indica uma maior contagem de composição bacteriana, e marrom também pode incluir hemoglobina. Tecido necrótico ou escara é compreendido como tecido morto e torna-se escuro na cor em razão da presença ou ausência de hemoglobina nos tecidos. Pode-se apresentar na cor preta ou marrom, de aspecto seco ou flutuante, aumentando o risco de infecção sistêmica, sepse e amputação. O desbridamento é indicado para qualquer ferida, aguda ou crônica, quando o tecido fibrinoso ou tecido necrótico estão presentes (BLACK et al., 2010).

O surgimento de úlceras pode ser inevitável principalmente em pacientes de UTI, de tal forma que, o estadiamento e a cicatrização precisam ser monitorados de modo efetivo, proposta da escala Pressure Ulcer Scale for Healing (PUSH). Essa escala foi desenvolvida e validada pelo Task Force da National Pressure Ulcer Advisory Panel (NPUAP) e traduzida para ser usada no Brasil por Santos et al 
(2005). Essa escala considera três parâmetros de avaliação que são: área da ferida, quantidade de exsudato e aparência do leito da ferida (NEPUAP, 2014).

O tamanho e o formato de uma ferida podem alterar durante o processo de cicatrização e/ou durante o tratamento. Algumas feridas podem parecer pequenas, entretanto a medida que os tecidos necrosados e desvitalizados são removidos, a ferida parece aumentar de tamanho. Isso ocorre porque a real extensão da ferida estava mascarada por esses tecidos. O monitoramento do tamanho e formato da ferida é importante para auxiliar na seleção da cobertura e os registros acurados são essenciais para monitorar a sua evolução (BERLOWITZ, BERMAN E SCHMADER, 2011; REIS et al., 2012).

A monitorização e a avaliação de uma ferida são tarefas complexas que exige do profissional a observação do maior número de informações possíveis para adequação do cuidado. Todos os métodos de avaliação devem ser utilizados em combinação para se ter uma visão mais acurada da evolução do cliente. O objetivo da avaliação é fornecer informações básicas sobre o estado da ferida, para que o seu processo possa ser monitorado assim como para assegurar que foi realizada uma seleção adequada dos produtos para seu tratamento (SIBBALD et al.,2006).

O odor está presente em feridas crônicas com presença de tecidos desvitalizados. Sabe-se que a necrose na ferida contribui para o aparecimento do odor, mas não pode ser vista como causa principal de seu surgimento. O odor desagradável é uma preocupação frequente e angustiante para pessoas com feridas infectadas, bem como para seus familiares e cuidadores. Pacientes com feridas fétidas muitas vezes experimentam isolamento social, depressão, vergonha, constrangimento e falta de apetite. Esses fatores configuram um impacto negativo em sua qualidade de vida, por isso a identificação e quantificação do odor é um parâmetro importante para o controle e a evolução do tratamento das lesões por pressão (CASTRO E SANTOS, 2015).

O odor é um sinal clínico de difícil mensuração e classificação, podendo ser usados os indicadores TELER (acrónimo para Treatment Evaluation by Le Roux Method). Este método é um sistema genérico que realiza notas clínicas e mede os resultados centrados no doente no que diz respeito aos cuidados e tratamentos à ferida. Pode ser aplicada a qualquer condição ou esfera de atividade, clínica ou não clínica, quando os resultados das intervenções necessitam ser medidos ao longo do tempo (MAIDA et al., 2009). 
A TELER é um instrumento de medição validado em feridas malignas que mede, em concordância com outros sintomas, a presença do odor em seis níveis, numa escala decrescente na intensidade: nível 5: sem odor; nível 4: o odor é detectado na remoção do curativo; nível 3: odor está evidente na exposição do curativo; nível 2: o odor é evidente a uma distância de aproximadamente meio metro do paciente; nível 1: o odor é evidente quando se entra na enfermaria em que se encontra o paciente; nível $0: 0$ odor é evidente quando se entra na casa/hospital/clínica em que se encontra o paciente (BOWLER et al., 2004).

A dor em LPP é um sintoma importante que apresenta grande interferência na adesão ao tratamento e na qualidade de vida dos doentes. Pode ser provocada pela própria etiologia da ferida, desbridamentos cirúrgicos, retirada, ressecamento e deslizamento da cobertura, movimento do paciente, fricção, isquemia e hipóxia dos tecidos, além de fatores ambientais e psicossociais. Pacientes com feridas crônicas vivenciam dor adicional no momento da troca de curativos, o que pode gerar sofrimento antecipado e prejuízos desnecessários (OLIVEIRA et al., 2005).

Para avaliar a dor causada pela LPP, os profissionais de saúde devem atentar para o início, a duração, a localização, e a intensidade da dor relatada. A intensidade dolorosa, pode ser medida por diversas escalas: Escala Númerica Verbal (ENV): O paciente emite nota para a dor de zero a 10, sendo zero na ausência de dor e 10 para dor insortável; Escala Visual analógica (EVA): mostra-se uma linha reta de 10 centimetros ao paciente e ele aponta o ponto de sua dor. Onde 0 significa sem dor e 10 dor insuportável; Escala de faces: registra-se o valor correspondente a cada face escolhida (FREEMAN et al., 2001).

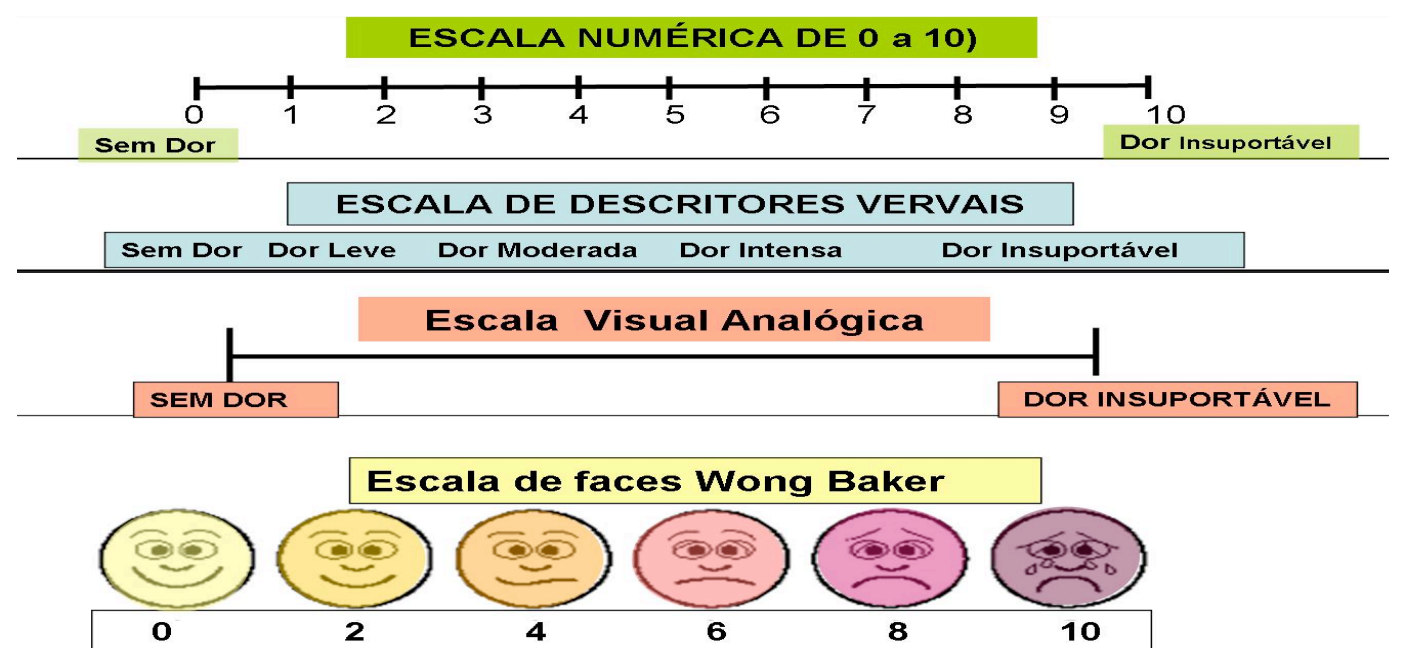

Figura 2 - Escala Númericas e Visuais Analógicas da Intensidade da dor 
A troca do curativo, a limpeza, o desbridamento e a retirada da cobertura anterior são procedimentos que provocam maior dor e podem interferir na reparação tecidual, por isso devem ser realizados com cautela. Falhas e inadequações neste proceso podem gerar traumas no leito e nas bordas da ferida, bem como na pele perilesional, especialmente quando a umidade é insuficiente e há tração e retirada de tecido viável (UPTON e ANDREWS, 2014).

\subsection{PRINCÍPIOS BÁSICOS NO TRATAMENTO DAS FERIDAS}

A identificação dos fatores de risco, a habilidade para o diagnóstico precoce, o conhecimento aprofundado dos processos de reparação tecidual e dos métodos e materiais usados para o cuidado das LPP, são requisitos essenciais quando se tem por objetivo melhorar a qualidade de vida da população, através de intervenções que aceleram o tempo de cicatrização, reduzindo a incidência, as complicações e o sofrimento dos pacientes (CHACON et al., 2009).

O envelhecimento, doenças crônicas, lesão medular são condições que desencadeiam inúmeras alterações que favorecem o aparecimento de LPP. A perda de massa corporal proporciona uma diminuição da coesão entre epiderme e derme, redução da sensibilidade e percepção sensorial e prejuizo na absorção e distribuição de nutrientes. Em geral, ocorre diminuição da resistência da pele à força de cisalhamento, o aumento da fragilidade vascular e a perda de tecido subcutâneo, que compromete a habilidade do tecido em redistribuir a carga mecânica sem prejudicar a circulação sanguínea (LISBOA, 2010).

O diagnóstico das LPPs é normalmente pautado em diferentes parâmetros, que proporcionam uma avaliação global da ferida e contribuem para escolhas mais acertivas dos procedimentos. Os parâmetros envolvem: Diagnóstico Etiológico, que define a origem da doença que propiciou o aparecimento da lesão cutânea; Causa, que define o mecanismo de ação para o aparecimento da LPP; Morfologia, que descreve a localização, número, dimensão e profundidade da lesão; Grau de contaminação, que define a lesão como limpa, contaminada ou infectada; Fase cicatricial, descrita como inflamatória proliferativa e de remodelação; Característica do exsudato, com presença, ausência, coloração e odor; Característica do leito da ferida, como necrótico, fribrinoso, granulação e epitelização; Evolução, como aguda ou crônica e; Tipo de cicatrização, como primária ou secundária (DEALEY, 2008). 
O reparo normal de feridas é um processo dinâmico, com interações complexas entre a matriz extracelular, a angiogênese controlada e as células da epiderme e da derme. Este processo dinâmico de reparo envolve três fases ordenadas: inflamação, proliferação e remodelação. Por outro lado, o reparo de feridas crônicas não tem processo ordenado e oportuno, não atingindo a integridade anatômica e funcional. As lesões por pressão são feridas crônicas, caracterizadas por estímulos inflamatórios persistentes tais como a repetição do trauma, isquemia relativa, e contaminação bacteriana, requerendo cuidados a longo prazo (WAYCASTER e MILNE, 2013).

A fase inflamatória é caracterizada pela hemostasia, resultante da formação do coágulo de fibrina, e migração de leucócitos fagocitários, os quais removerão as substâncias estranhas e microrganismos. A fase proliferativa envolve, principalmente, a migração e proliferação de três classes celulares: fibroblastos, endotélio e queratinócitos, além da deposição de fibronectina sobre o arcabouço de fibrina. Na última fase ocorre mudança no padrão de organização do colágeno e de seu tipo principal, ocorrendo substituição de colágeno III por I. Todo o processo de cicatrização é controlado por polipeptídeos chamados fatores de crescimento, que modificam a fisiologia de suas células-alvo (SOLEY et al., 2016).

O conceito do preparo do leito da ferida está focado nos pontos críticos da ferida crônica, que são o debridamento de tecido inviável, equilíbrio bacteriano e inflamatório e a manutenção da umidade. Onde, o objetivo final é promover a formação de um tecido de granulação de qualidade e favorecer a epitelização total da ferida, de forma fisiológica ou utilizando produtos que facilitem esses processos (PERCIVAL e SULEMAN, 2015).

A exsudação e os tecidos presentes na ferida têm papel preponderante no processo cicatricial. Uma exsudação abundante, normalmente indica um prolongado estágio inflamatório ou infecção; e a presença de tecidos desvitalizados no leito da lesão prejudica a regeneração do tecido saudável (BROWN-ETRIS et al., 2008).

As feridas contaminadas ou colonizadas apresentam uma carga bacteriana que interfere no processo de cicatrização, pois a capacidade de replicação bacteriana é alta. Um dos sinais e sintomas da ferida colonizada, são a cicatrização retardada, aumento do volume de exsudato, mudanças no padrão da dor, alteração do odor e pele peri-lesão hiperemiada (SIBBALD et al., 2006). 
Existem diferentes tipos de debridamento, que consiste na remoção de tecidos desvitalizados presentes no leito da ferida, os quais formam uma barreira à migração das células, aumentam o risco de infecção e retardam o início da proliferação celular para o preenchimento da lesão. Segundo Iron (2005), existem quatro tipos básicos: 1- desbridamento mecânico: remoção rápida do tecido necrosado de uma ferida por meio do atrito mecânico ou escovação; 2desbridamento químico: utiliza versões exógenas de enzimas de ocorrência natural, como as enzimas proteolíticas e a colagenase; 3- desbridamento autolítico: envolve o uso de curativos sintéticos para cobrir a ferida e permite a autodigestão do tecido desvitalizado por enzimas normalmente presentes nos fluidos da lesão e 4desbridamento cirúrgico: é o método de escolha para a remoção rápida de grandes quantidades de tecidos desvitalizados, utiliza instrumentais esterilizados, podendo ser realizado em ambiente cirúrgico ou a beira do leito, conforme a condição da lesão bem como a condição clínica do paciente.

O tratamento de uma LPP depende do estágio e da severidade da lesão e inclui a eliminação ou redução de fatores de risco associados a seu desenvolvimento e a promoção do cuidado local à ferida, que compreende a remoção de tecido desvitalizado, com as diversas formas de desbridamento, manutenção do meio úmido e aplicação de coberturas que propiciem sua cicatrização (LO et al., 2008).

Em dados mundiais, as LPPs afetam cerca de 1 milhão de pessoas a cada ano, levando a um custo anual de aproximadamente US \$1,6 bilhões. A publicação das diretrizes de prática clínica pela Agência de Política de Saúde e Pesquisa (AHCPR) na ultima década, aborda protocolos de prevenção, diagnóstico e tratamento das lesões por pressão, mesmo assim o tempo de internação e os custos associados com estas lesões continuam aumentando (SPETZ et al.,2013).

O elevado número de pessoas que desenvolvem LPP contribui para onerar o gasto público do Sistema Único de Saúde (SUS), além de interferir na qualidade de vida desses pacientes e de seus cuidadores. As lesões estão associadas ao aumento do tempo de internação, na carga de trabalho para enfermagem e no aumento de custos, além de maior morbidade e mortalidade dos pacientes (BRASIL, 2009).

Neste sentido é muito importante a realização de pesquisas clínicas controladas para ampliação do conhecimentos da equipe de saúde e também desenvolvimento de métodos e materiais para o tratamento eficiente das LPP(s). É 
válido salientar que profissionais qualificados e a motivação do paciente em restaurar a saúde, são fatores primordiais no sucesso terapêutico (MALAGUTTI, 2015).

\subsection{CURATIVOS DE HIDROGEL COM NANOPARTÍCULAS DE PRATA}

Borges (2012) explica que, o termo curativo é o ato de limpar, desbridar e

cobrir lesões. Os materiais desenvolvidos para o curativo das feridas são denominados coberturas.

Uma cobertura ideal segundo Turner (1984), Girardi (2005) e Park et al., (2015) segue os critérios, que incluem: prover e manter um ambiente úmido; proteger a ferida contra infecções secundárias, agindo como uma barreira antibacteriana; permitir trocas gasosas adequadamente; prover isolamento térmico; ser livre de partículas ou contaminantes tóxicos; manejar o excesso de exsudato; permitir uma remoção não traumática; apresentar elasticidade, não antigenicidade; ter um baixo custo; ser durável e ser ajustável a feridas com superfícies irregulares.

Os hidrogéis podem ser usados como curativos, pois mantém o leito da ferida úmido, facilitando as enzimas intrínsecas do corpo a quebrar o tecido necrosado ou não viável, propiciando a regeneração celular (WANG et al., 2007). As propriedades que tornam os hidrogéis biomateriais são o seu elevado teor de água, que contribui para sua biocompatibilidade; baixa tensão interfacial, que melhora sua capacidade de adesão aos tecidos orgânicos e absorção de proteínas e de fluidos teciduais; propriedades físicas semelhantes aos tecidos orgânicos, representada pela sua maciez e elasticidade, que minimiza a irritação mecânica ao atrito; estrutura porosa que permite a difusão de metabólitos e boa permeabilidade ao oxigênio (PATEL e MEQUANIT, 2011).

Os produtos com hidrogéis para feridas já são comercializados sob as formas de gel amorfo e placa/membranas. As placas de hidrogel são usadas como curativos primários para feridas planas, isto é, sem cavitações. (ALMEIDA et al., 2002). A maioria dos hidrogéis para curativo são importados para o Brasil, o que torna os custos do uso desse produto oneroso para um elevado número de pacientes portadores de feridas crônica (LIMA e GUERRA, 2011).

Hidrogel é uma rede tridimensional composta por polímeros reticulados, com 
grande capacidade de absorver água e fluidos biológicos sem perder sua integridade estrutural. O modelo de hidrogel usado como curativo foi desenvolvido por Rosiak et al., sendo uma blenda polimérica de poli(N-vinil-2pirrolidona) (PVP), polietilenoglicol (PEG) e ágar apresentando boas propriedades biológicas (ROSIAK et al., 1989; LUGÃO et al., 1998).

As membranas de hidrogel usadas como coberturas de feridas podem ser produzidas por processos físicos ou agentes químicos. O uso da radiação na formação de hidrogéis possibilita a reticulação e esterilização simultânea, permitindo a síntese de um produto não contaminado com resíduos tóxicos de iniciadores, além de ser uma tecnologia que permite a simplificação do processo de produção e redução de custos (BENAMER et al., 2006).

A formação da membrana por meio da radiação ionizante pode ser explicada como um resultado de recombinação mútua de macromoléculas. Se radicais livres localizados nas cadeias poliméricas estiverem favoravelmente posicionados, eles poderão sofrer recombinações. Como resultados desse processo são formadas ligações covalentes entre estas moléculas. Se a quantidade destas novas ligações forem suficientemente grandes aparece no sistema uma fração de gel insolúvel. Não há necessidade de introduzir iniciadores (normalmente superóxidos tóxicos) no sistema e o processo ocorre à temperatura ambiente (ROSIAK et al., 1999; LUGÃO e MALMONGE, 2001; SINGH, SINGH e SINGH, 2012).

O hidrogel também pode ser aplicado como matriz para sistemas de liberação controlada de princípios ativos e agentes antimicrobianos. A incorporação das substâncias terapêuticas nas membranas de hidrogel e a liberação destes agentes na ferida é resultado de uma série de fatores definidores pelo grau de reticulação produzido pela irradiação. As espécies geradas radioliticamente exibem um forte poder redutor, por isso a radiação gama tem sido empregada na redução de íons de metais para a síntese de nanopartículas em solução, em especial as nanopartículas de prata (SHIN, et al.,2004).

A prata é um metal obtido em grande parte como subproduto da mineração do chumbo, é encontrado, frequentemente associado ao cobre e suas propriedades medicinais têm sido usadas por mais de 2000 anos. A ação antimicrobiana da prata é o motivo principal de sua aplicação médica, com grande potencial para o tratamento de ferimentos (SAMBERG et al., 2012). 
Os revestimentos com prata têm sido utilizados progressivamente no tratamento de feridas. Atualmente, a prata está presente em uma grande variedade de coberturas, podendo apresentar duas formas: 1) compostos/complexos quando associado com um sal de prata, que produz a prata iónico $(\mathrm{Ag}+)$ quando em contato com fluidos ou soluções das feridas; 2) prata elementar em suporte metálico $\left(\mathrm{Ag}^{0}\right)$, também descrita como prata coloidal e nanopartículas de prata (BELONI, 2006).

A prata nanocristalina foi introduzida como curativo em 1998, com a alegação de que ela reduz a ocorrência de infecção e oferece uma oportunidade para melhorar a prática clínica no tratamento de feridas. Apesar dos gregos e romanos já usarem a prata como agente bactericida desde a antiguidade, a prata coloidal só passou a despertar interesse nos pesquisadores depois do surgimento da resistência bacteriana a antibióticos e dos avanços da nanotecnologia (NOWACK et al., 2011).

A membrana de hidrogel com nanopartículas de prata representa uma das alternativas utilizadas no tratamento de feridas crônicas. Esse tipo de cobertura soma os benefícios do hidrogel com a ação antimicrobiana da prata. O tratamento com curativos com nanopartículas de prata objetiva reduzir carga biológica da ferida, tratando a infecção local evitando a disseminação sistêmica. As diretrizes clínicas recomendam que curativos com nanopartículas de prata sejam utilizados em feridas onde a infecção já esteja estabelecida ou uma ferida com carga microbiana excessiva, e que isto retarde a cicatrização (PALADINI et al.,2013).

Os curativos de hidrogel com nanopartículas de prata apresentam largo espectro de ação antimicrobiana. Estudos in vitro demonstraram sua atividade bactericida em cepas de microrganismos resistentes a antibióticos, dentre os quais: Staphylococcus aureus multiresistente, Pseudomonas aeruginosa, E coli, Enterobacter, Klebisiela sp, e Candida Albicans (BOWLER e JONES, 2004).

Uma preocupação da aplicação dos curativos de hidrogel com nanopartícula de prata é o seu potencial efeito citotóxico contra os tecidos orgânicos. Entretanto, um estudo de Monteiro, et al., (2009) mostrou que, testes de citotoxidade de diferentes tipos de hidrogéis testados não apresentaram efeito negativo para as células humana. A liberação da prata depende da natureza de concentração deste metal, bem como o tipo da matriz polimérica. Em concentrações baixas $\left(<\mathrm{IC}_{50 \%}\right)$ estes curativos não foram considerados citotóxicos. 
Os hidrogéis à base de PVP e NPAg produzidos pelo IPEN mostraram características adequadas para uso como curativos de feridas, tendo em vista suas propriedades de manter o ambiente úmido e combater a infecção, facilitando as enzimas intrínsecas do corpo a quebrar o tecido necrosado ou não viável, propiciando a regeneração celular. Assim como o hidrogel utilizado por JONES e VAUGHAN (2005).

\subsection{Aplicação de curativos de hidrogel com nanopartículas de prata.}

Thomas (2008) realizou um estudo observacional com três pacientes com internação de longo prazo, cada um com lesões por pressão em estágio II. A terapia de feridas foi realizada com tratamento padrão, que incluiu óleo, hidrogel; hidrocolóides e hidrogel com prata. Foram observadas mudanças no aspecto e dimensões da ferida como critérios de evolução do tratamento. Em um ambiente de cuidados de longo prazo, as coberturas com prata, adicionada ao padrão de cuidado pode acelerar a cicatrização de lesões por pressão em estágio 2 .

WU et al (2009) estudaram a síntese, o processamento e o comportamento antimicrobiano de novas membranas de hidrogel termoplástico contendo prata. A atividade antimicrobiana foi examinada utilizando a exposição a Escherichia coli. Hidrogéis de nanofibras contendo prata exibiram destaque excepcional contra a resistência do biofilme nas culturas bacterianas. A aplicação dos hidrogéis antimicrobianos como curativos combinam propriedades do hidrogel com a ação bactericida da prata e configuram uma boa opção no tratamento de feridas crônicas.

Em seu estudo, Ammons, Ward, James (2011), demonstraram que a obesidade combinada com o envelhecimento da população, provocou um aumento expressivo na incidência de feridas crônicas, como lesões do pé diabético, lesões por pressão e lesões venosas. O biofilme bacteriano é um dos principais contribuintes na produção das lesões teciduais e interferência no processo cicatricial normal. $O$ hidrogel em combinação com a prata (curativo Acticoat ${ }^{\mathrm{TM}}$ ) apresentou uma redução significativa na viabilidade do biofilme em relação à ferida em uso de hidrogel disponíveis comercialmente. Curativos desenvolvidos com tecnologia de baixo custo podem ser aplicados com a mesma efetividade que os curativos industrializados e patenteados. 
Chakavala et al (2012) desenvolveram uma cobertura de hidrogel, contendo sulfadiazina de prata para cicatrização de feridas de queimaduras. O hidrogel foi preparado por reticulação de PVA e quitosano. As propriedades do gel, tais como a capacidade de retenção de umidade, capacidade de absorção de líquidos e liberação da prata foram avaliados in vitro. O hidrogel contendo $7,5 \%$ de PVA e 0,75\% de quitosano mostrou aumento da força do gel, e da taxa de transmissão de vapor de água e maior capacidade de absorção de líquidos, sendo apropriado para uma cicatrização mais rápida de queimaduras. Este hidrogel também sofreu a liberação de $1 \%$ sulfadiazina de prata requerido para longa atividade antimicrobiana. Assim hidrogel contendo $7,5 \%$ de PVA, $0,75 \%$ de quitosana e $1 \%$ de sulfadiazina de prata é considerado uma boa indicação de curativo para queimaduras.

Já no estudo de Neibert et al (2012) avaliaram a fabricação e aplicação de curativos de fibras de alginato, covalentemente reticulados e carregados com nanopartículas de prata. Este estudo sugere que as nanopartículas de prata carregados em fibras de alginato podem ser facilmente aplicadas em um paradigma de cicatrização de feridas, promovendo o processo de reparação e migração de fibroblastos à área lesionada, redução da fase inflamatória e o aumento da espessura da epiderme na área da ferida, melhorando assim a qualidade global e a velocidade de cura.

Foi realizado um estudo de revisão sistemática sobre os efeitos dos curativos em queimaduras, baseando-se em seus efeitos na ferida, a facilidade de aplicação e remoção, os requisitos de troca de curativo, custo e conforto do paciente. Um total de 30 ensaios clínicos randomizados foram incluídos nesta revisão. Queimaduras tratadas com curativos de hidrogel parecem curar mais rapidamente do que aqueles tratados com outras coberturas. Há uma escassez de evidências de alta qualidade sobre o efeito de diferentes curativos na cicatrização de lesões de queimaduras, sendo impossível tirar conclusões definitivas e confiantes sobre a eficácia de curativos específicos (WASIAK ET AL., 2013),

Paladini et al. (2013) propuseram a introdução de partículas de prata na estrutura fibrilar de derivados de di-fenilalanina aromáticos de auto-montagem modificados para produzir curativos de feridas com propriedades antibacterianas. Hidrogéis com quantidades crescentes de prata foram testados e a influência da prata sobre a estrutura de hidrogéis foi estudada utilizando luz e microscopia confocal. O potencial antibacteriano deste curativo foi demonstrado po meio de 
exames microbiológicos com Staphylococcus aureus. A combinação das propriedades antibacterianas e propriedades físico-químicas, com a facilidade de preparação desses biomateriais, satisfaz a exigência de coberturas clinicamente eficazes.

Galli, Protzman, Brigido (2013) avaliaram a atividade antimicrobiana de curativos de hidrogel com nanopartículas de prata em incisões cirúrgicas de pé e tornozelo em cinquenta e nove pacientes. No geral, houve $5(8,47 \%)$ casos de infecções: 4 (6,78\%) superficiais e 1 (1,69\%) de profundidade. A menor incidência de complicações incisionais e uma maior redução do comprimento da cicatriz sugerem que as propriedades inerentes do hidrogel com nanopartículas de prata configuram com uma boa alternativa de curativos que favorecem a cicatrização pós-cirúrgica.

Em um estudo realizado por Oliveira et al. (2014) desenvolveram hidrogéis de álcool polivinílico (PVA) com nanoparticulas de prata PVA, gama-irradiado para uso potencial em queimadura. O nitrato de prata (AgNO3) foi usado como agente precursor de nanonopartícula de prata e uma solução salina, tamponada com fosfato com $\mathrm{pH}$ 7,4 e pH 4,0 foram utilizadas como meio experimental. Ambas as amostras de PVA/nanoparticula de Ag foram não-tóxicos e apresentaram boa atividade antimicrobiana, confirmando que $0,25 \%$ de concentração de AgNO3 é suficiente para estabelecer um efeito microbicida. Ambas as amostras PVA-AG apresentaram propriedades mecânicas adequadas, representando potenciais efeitos de reparo na área da queimadura.

Khampieng, Brikshavana, SIpaphol (2014), avaliaram as propriedades físicas e biológicas de curativos de hidrogel com nanopartículas de prata (NPAg) preparados por irradiação gama, em várias doses: 25, 35, e 45 kGy. A formação e as características das nanopartículas de prata foram investigadas com microscopia eletrônica de transmissão e microscopia eletrônica de varredura com raio-X de energia dispersiva. A propriedade antibacteriana dos curativos testados foi eficaz, com atividade bactericida de 99,99\% em 12 h e 6 h, respectivamente. A avaliação da citotoxicidade indicou que tanto o hidrogel puro e os hidrogéis de NPAg eram nãotóxicos para os fibroblastos. Os hidrogéis PVP com NPAg-incorporados não apenas forneceram um ambiente limpo e úmido para a cicatrização de feridas, mas também efetivamente impediram infecção bacteriana e acelerou o processo de recuperação das feridas. 
Com relação à atividade antimicrobiana da prata, Wang et al. (2014) relacionaram sua toxicidade dose dependente. Neste estudo, um composto de NPAg foi fabricado por carregamento num hidrogel de alginato seco. A atividade antimicrobiana contra $E$. coli e $S$. aureus demonstraram que a prata liberada causou uma redução de $100 \%$ das bactérias. A concentração de prata liberada não foi tóxica para cultura de células humanas e permitiu crescimento de células da cultura teste. Estes resultados demonstram, que o desempenho do presente composto pode permitir a gestão da infecção bacteriana em leitos de feridas sem comprometimento da reparação tecidual.

Adhya et al (2014) realizaram um estudo controlado e randomizado para comparar a eficácia de hidrogel com NPAg e sulfadiazina de prata tópica no tratamento de queimaduras. Pacientes com queimaduras de segundo grau foram alocados aleatoriamente para os dois grupos de tratamento, e a avaliação clínica da queimadura foi feita em quatro semanas e após a conclusão do tratamento. A membrana de hidrogel com NPAg foi uma alternativa eficaz e superior à sulfadiazina de prata no tratamento de queimaduras, particularmente em queimaduras de segundo grau profundas. A cicatrização pode ser esperada, em geral, em 6-8 semanas, dependendo do grau de envolvimento da superfície corporal.

SACCO et al. (2015), estudaram uma nova técnica baseada na difusão lenta de tripolifosfato, para a preparação de hidrogéis de quitosano para obter membranas flexíveis e macias que incluem NPAg. Uma investigação exaustiva sobre as propriedades bactericidas do material indicou a atividade sinérgica de quitosano e NPAg para reduzir o crescimento de $S$. aureus, E. coli, S. epidermidis, $P$. aeruginosa e também mostrou quebra de biofilmes. Ensaios de biocompatibilidade em queratinócitos e fibroblastos também foram realizados e não mostraram quaisquer efeitos nocivos sobre a viabilidade das células. Esta nova técnica permite a produção de membranas bioativas com grande potencial para o tratamento de feridas crônicas.

Singh, Singh e Singh (2015) avaliaram a ativiade antimicrobiana de diferentes hidrogéis com nanopartículas de prata. Os hidrogéis foram preparados utilizando polivinilpirrolidona (PVP) preparados utilizando 10\% e 15\% de PVP. Uma base de gel $15 \%$ de PVP com dose de radiação de $25 \mathrm{kGy}$ foi selecionada para a preparação de hidrogéis com NPAg. Os hidrogéis com 100 ppm NPAg demonstraram eficiente atividade microbicida contra patógenos de feridas, como $P$. aeruginosa, S. aureus, $E$. 
coli e C. albicans. Foi possível determinar que hidrogéis de PVP contendo nanopartículas de prata, podem ser usados como coberturas para feridas para controlar a infecção e facilitar o processo de cicatrização de lesões da pele.

Sunarti (2015) relatou um caso de lesão por pressão, onde foi aplicado como cobertura primária uma membrana de hidrogel. O curativo proposto protegeu a ferida, absorveu exsudado e manteve uma base úmida na ferida. Foi possível observar as fases de cura da ferida, identificando a limpeza, granulação e epitelização.

Park et al. (2015) testaram hidrogéis biocompatíveis em cicatrização de feridas. Feridas abertas foram utilizadas como modelo para avaliar os efeitos de hidrogéis nas diversas fases de cicatrização. Nos dias 7 e 14 pós-ferimento, feridas tratadas com hidrogéis foram muito reduzidas em tamanho em comparação às feridas que receberam outros tratamentos. A ferida tratada com hidrogel mostrou regeneração epitelial quase completa, com a maturação do tecido conjuntivo e formação de tecidos de epitelização.

Em outro estudo, El-Naggar et al. (2015) conduziram uma abordagem alternativa de uma cobertura de hidrogel de quitosana com prata para o tratamento de infecção de feridas produzidas em ratos com bactérias multi-resistentes colhidas em pés diabéticos. Sessenta e cinco amostras bacterianas foram isoladas de quarenta pacientes diabéticos. S. aureus e Pseudomonas aeruginosa foram predominantes nas amostras examinadas nas lesões em comparação com as outras espécies. A fórmula proposta do hidrogel de quitosano com prata mostrou atividade antibacteriana e boa propriedade de cura em feridas infectadas sem efeitos colaterais nos rins e funções hepáticas dos grupos testados.

Bhowmick e Koul (2016) testaram uma membrana de hidrogel com NPAg, em culturas bacterianas para determinar o seu potencial antimicrobiano. A concentração inibitória mínima (MIC) das NPAg para o Staphylococcus aureus e Escherichia coli foi estimada em $7.81 \mu \mathrm{g} / \mathrm{mL}$, enquanto que para a Pseudomonas aeruginosa (gram negativos) foi cerca de $3.90 \mu \mathrm{g} / \mathrm{mL}$. A eficácia antimicrobiana dessa membrana foi mantida, mesmo depois de 96 horas de libertação de NPAg, sugerindo que pode ser usada como um reservatório para manter um ambiente úmido e estéril durante um longo período de tempo. 


\section{RESULTADOS}

Serão apresentados e descritos a seguir, os casos clínicos de 6 (seis) feridas de cinco pacientes portadores de LPP em região trocantérica. As fotografias demonstradas se referem aos períodos: inicial, 7 dias e 15 dias pós curativos.

\section{Paciente 1}

Paciente 64 anos, gênero feminino, leucoderma, com diagnóstico de reumatismo e lesão por pressão em região do trocanter direito e esquerdo, ambos de categoria III, respectivamente com 1(um) e 3 (três) meses de evolução.

\section{- Trocanter Direito $1^{\mathrm{A}}$ :}

A lesão por pressão na avaliação inicial apresentava tecido de fibrina em bordas e tecido de granulação no leito da ferida, com escasso exsudato, isto é, umidade da cobertura secundária maior que $50 \%$, odor na exposição da cobertura (Score 3) e EVA de 8 na retirada do curativo anterior. O resultado da coleta de secreção, realizado por swab, apresentou a presença de Acinetobacter baumannii.

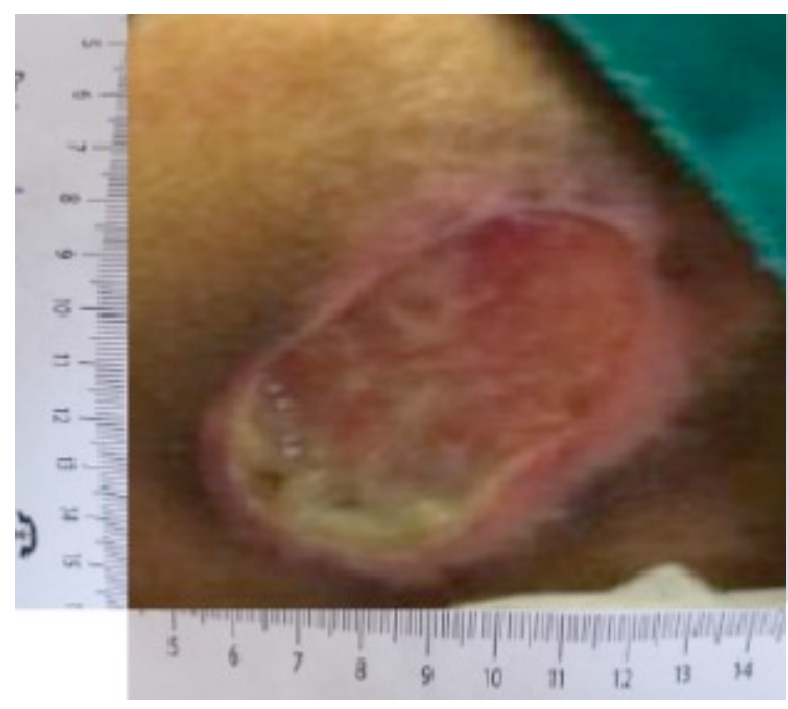

Figura 4A- Região do trocanter Direito, foto inicial

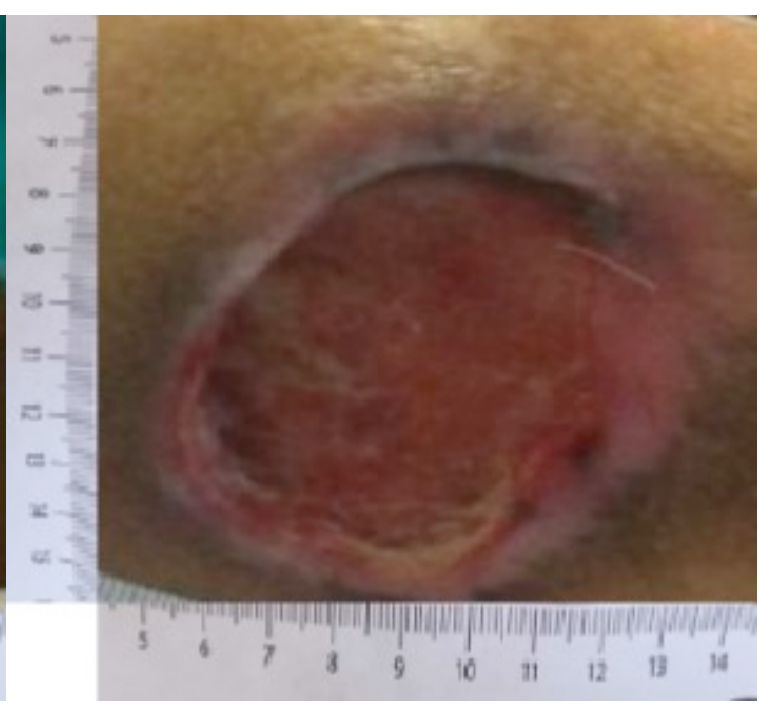

Figura 4B- Região do trocanter Direito, após 15 dias

De acordo com a análise métrica, a lesão se encontrava com uma área total de 21,2 $\mathrm{cm}^{2}$ (FIGURA 4A). Após 15 dias de tratamento com hidrogel com nanopartícula de prata (NPAg), houve uma melhora no tecido da ferida, com a retirada total do tecido 
desvitalizado e uma regressão da área da lesão $\left(19,2 \mathrm{~cm}^{2}\right)$. Outro ponto importante foi a ausência de odor (score 5) e dor (EVA 2) durante a troca do curativo (FIGURA 4B). Quanto a presença de secreção houve ausência de exsudato no curativo secundário.

\section{- Trocanter Esquerdo $1^{\mathrm{B}}$}

A lesão por pressão no período inicial (FIGURA 5A) apresentava tecido de fibrina em sua maior área e pequeno percentual de tecido de granulação, com quantidade moderada de exsudato, odor fétido na exposição da cobertura (score 3) e EVA de 8 na retirada do curativo anterior. O resultado da coleta de secreção apresentou a presença de Acinetobacter baumannii.

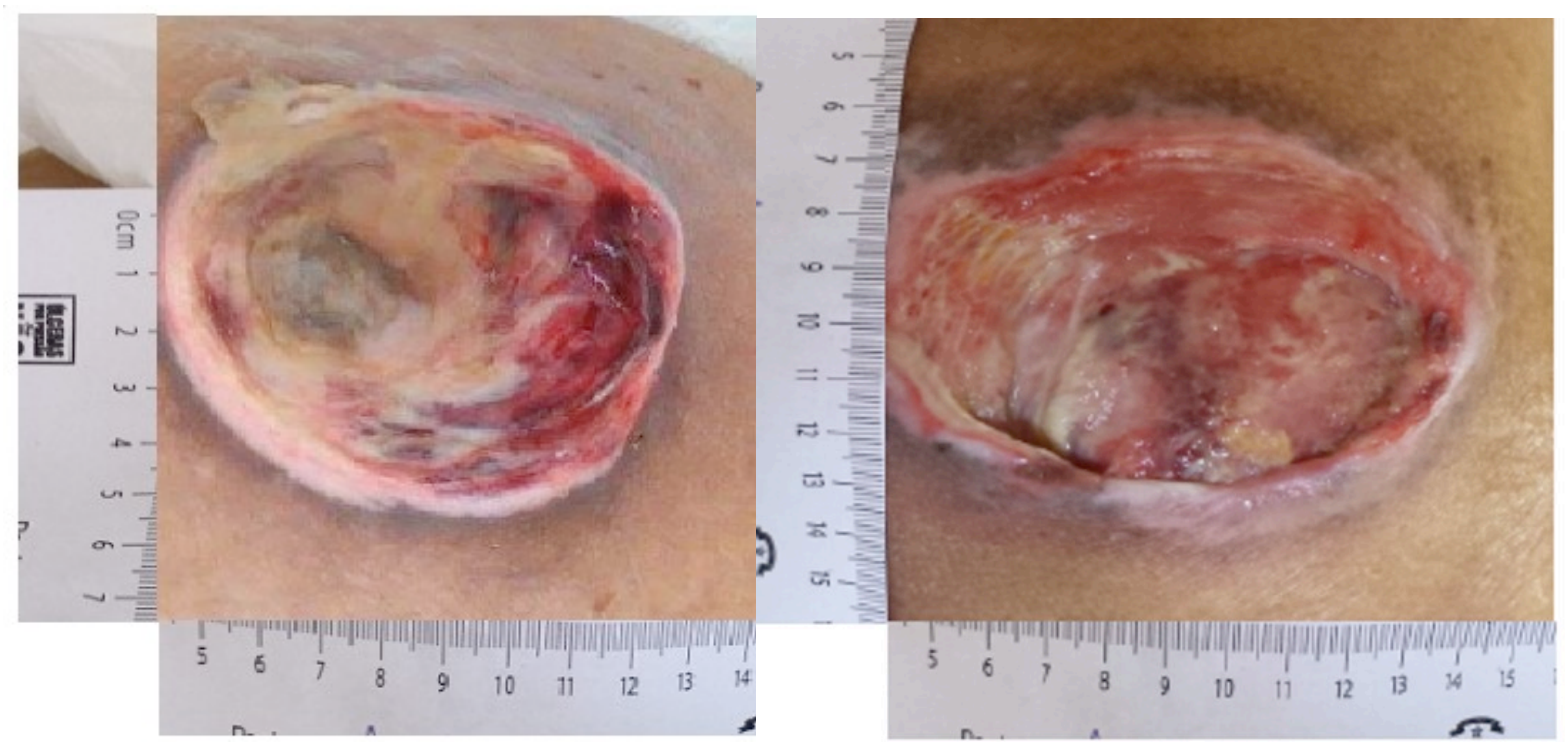

Figura 5A- Região do trocanter esquerdo,

Figura 5B- Região do trocanter esquerdo, após 15 dias de tratamento

De acordo com a análise métrica, a lesão apresentava uma área total de 31,3 $\mathrm{cm}^{2}$. Após 15 dias de tratamento com hidrogel com NPAg, houve uma melhora no tecido da ferida, com a diminuição significativa do tecido desvitalizado, e com isto um aumento no tamanho da lesão $\left(37,5 \mathrm{~cm}^{2}\right)$. Outro ponto importante foi a ausência de odor (score 5) e dor (EVA 2) durante a abertura do curativo e escassa presença de secreção. 


\section{Paciente 2}

Paciente 90 anos, gênero feminino, leucoderma, com diagnóstico de Pneumonia e LPP em região do trocanter com evolução de 1 mês, de categoria não mensurável devido ao tecido necrótico em toda área da lesão (FIGURA 6A).

LPP com área inicial de $35,9 \mathrm{~cm}^{2}$, nenhum exsudato, leito da lesão seco, com odor fétido acentuado (score 2) e bordas hiperemiadas. O resultado da coleta de secreção apresentou a presença de Stephylococcus aureus. Ao avaliar a dor através da EVA foi obtido score de 6, ao retirar o curativo anterior, que se encontrava muito aderido na lesão. Não foi realizada coleta de secreção, em virtude da presença de crosta em todo leito da ferida.

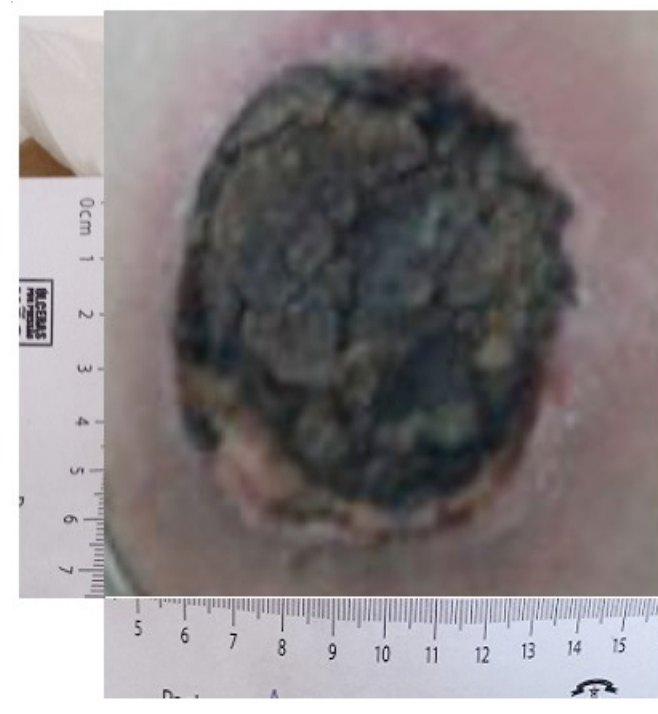

Figura 6A: Região do trocanter Direito, foto inicial

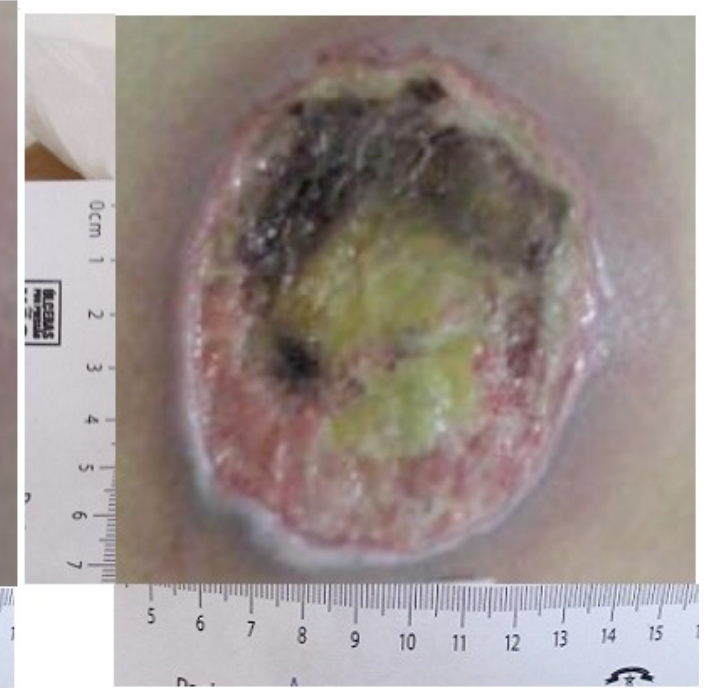

Figura 6B: Região do trocanter Direito, 15 dias após tratamento

Após 15 dias de tratamento com hidrogel NPAg, houve uma melhora no tecido da ferida, com a diminuição significativa do tecido necrótico, e a presença de tecidos viáveis, com isto um aumento no tamanho da lesão $\left(39,1 \mathrm{~cm}^{2}\right)$. Na figura 6 , pode-se perceber uma melhora da hiperemia nas bordas da lesão e a presença da umidade no leito. Quanto a queixa de dor na retirada do curativo, houve diminuição do score de EVA para 2.

\section{Paciente 3}

Paciente 80 anos, gênero masculino, melanoderma, com diagnóstico de acidente vascular encefálico e lesão por pressão com evolução de 4 meses, em 
região do trocanter esquerdo, de categoria não mensurável devido ao tecido necrótico em grande parte da lesão (FIGURA 7A). Apresentava-se friável ao retirar curativo anterior.
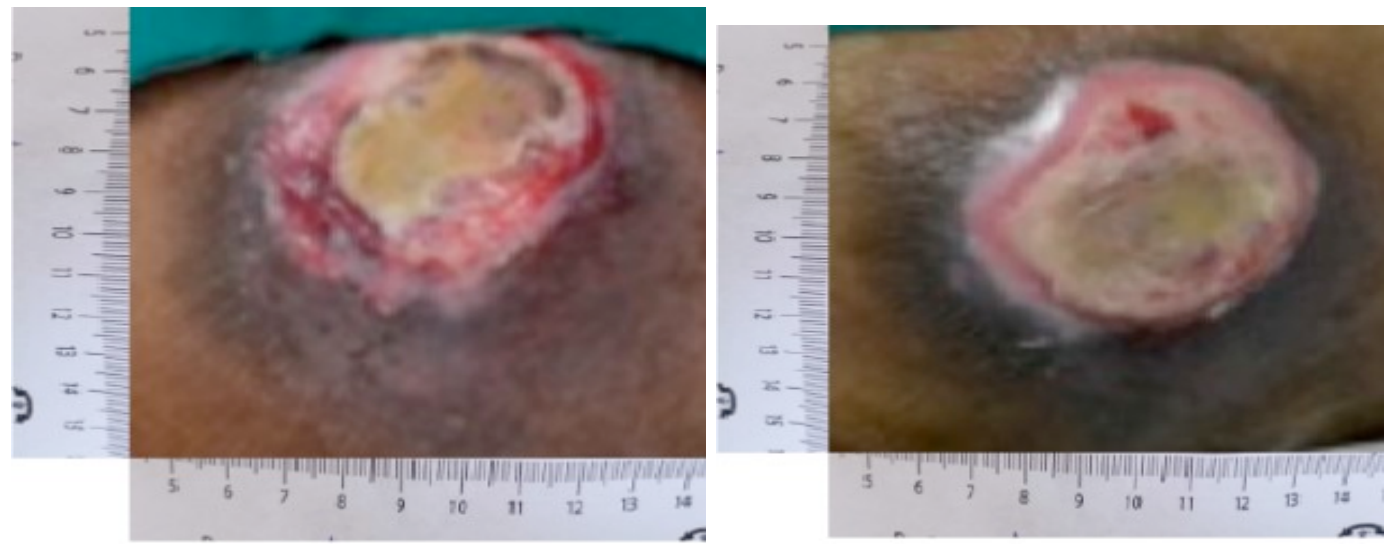

Figura 7A: Região do trocanter esquerdo, foto inicial Figura 7B: Região do trocanter esquerdo, após 15 dias de tratamento

De acordo com a análise métrica, a lesão se encontrava com uma área total de $25,2 \mathrm{~cm}^{2}$, presença de tecido necrótico, friável a manipulação, odor score 3 . Após 15 dias de tratamento com hidrogel NPAg, não houve uma melhora significativa do tecido desvitalizado presente na ferida. Mas houve uma diminuição no tamanho da lesão $\left(20,74 \mathrm{~cm}^{2}\right)$, observando com isso uma melhora do aspecto visual da lesão, com ausência de sangramento ao retirar o curativo com hidrogel. No quesito odor, houve uma pequena diminuição, com score 4. O resultado da coleta de secreção apresentou a presença de Pseudomonas aeroginosa. Não foi avaliado EVA de dor devido paciente apresentar plegia de membros inferiores. (FIGURA 7B)

\section{Paciente 4}

Paciente 82 anos, gênero feminino, leucoderma, com diagnóstico de pneumonia e LPP em região do trocanter direito, com evolução de 6 meses, de categoria III (FIGURA 8A).

De acordo com a análise métrica, a lesão se encontrava com uma área total de $24,1 \mathrm{~cm}^{2}$ e profundidade de $3 \mathrm{~cm}$. Apresentava tecido desvitalizado e presença de secreção em quantidade escassa, odor fétido (score 3). Em relação a queixa de dor durante o procedimento do curativo, o paciente relatou dor moderada, pontuando o valor de 7 na Escala Visual Analogica (EVA). O resultado da coleta de secreção apresentou bactéria Klebsiella pneumoniae. 

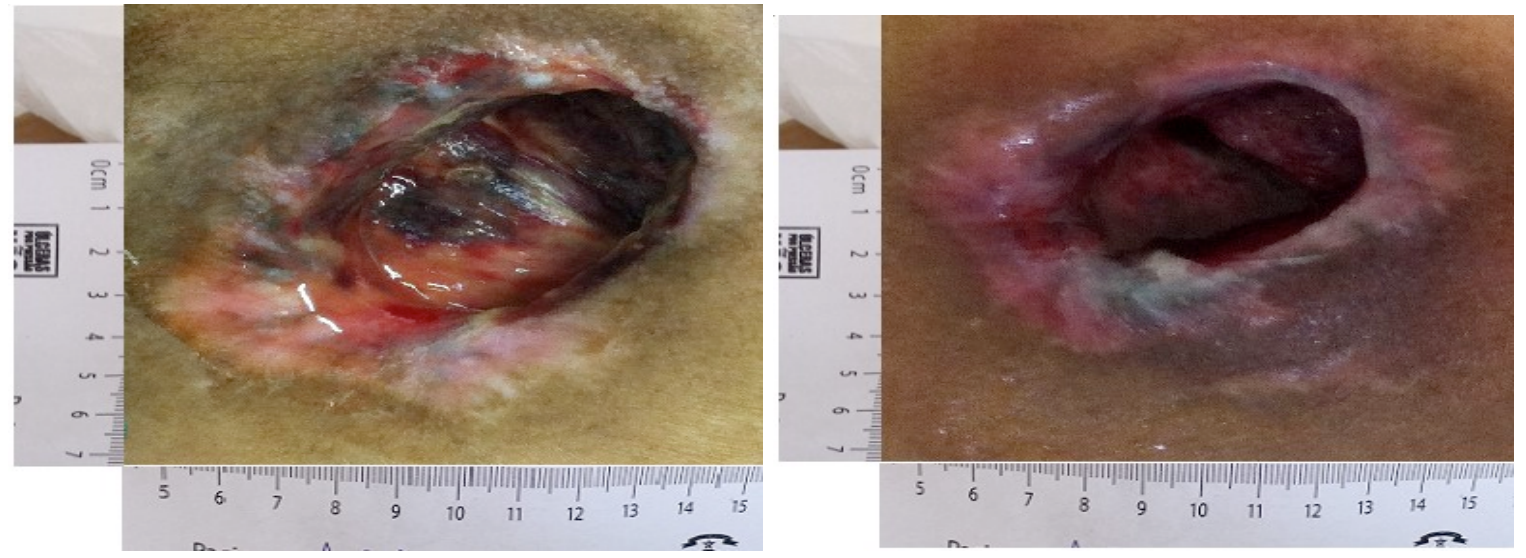

Figura 8A: Região do trocanter Direito, foto inicial. Figura 8B: Região do trocanter Direito, após 15 dias de tratamento.

Após 15 dias de tratamento com hidrogel com NPAg, houve uma melhora no tecido da ferida, com presença de tecido de granulação em toda área, e bordas com melhora do aspecto visual. Houve um aumento no tamanho da lesão $\left(25,4 \mathrm{~cm}^{2}\right)$, e da profundidade $(3,9 \mathrm{~cm})$, com relato de diminuição da dor, EVA 2, odor com score 5 , e nenhuma secreção durante a troca do curativo (FIGURA 8B).

\section{Paciente 5}

Paciente 68 anos, gênero masculino, leucoderma, com diagnóstico de lesão cervical por acidente motociclístico, há aproximadamente 1 ano. Apresentando LPP em região do trocanter direito, de categoria 3, com evolução de 6 meses, odor com score 3 , e secreção de moderada quantidade. A lesão se encontrava com uma área total de $45,7 \mathrm{~cm}^{2}$. Não foi avaliado EVA de dor, pois o paciente apresenta plegia de membros inferiores. $O$ resultado da coleta de secreção apresentou bactéria Pseudomonas aeroginosa (FIGURA 9A). 


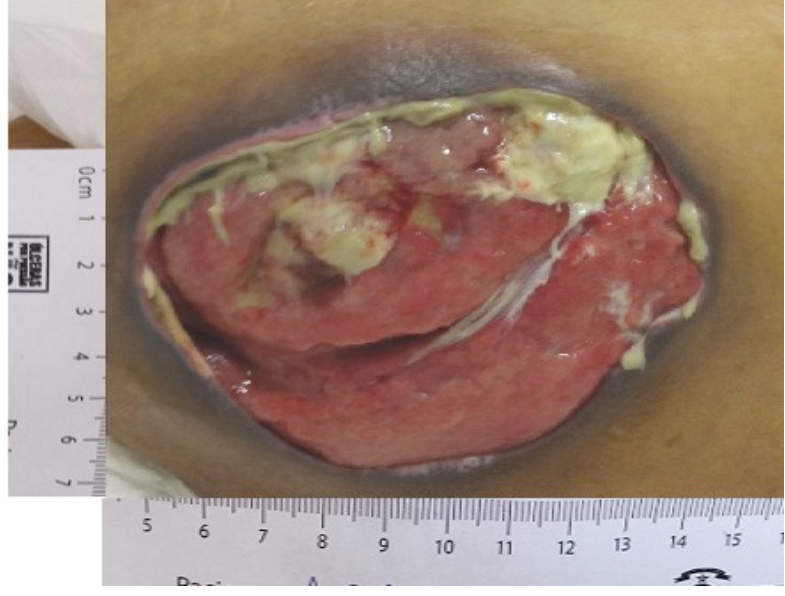

Figura 09A: Região do trocanter Direito, foto inicial

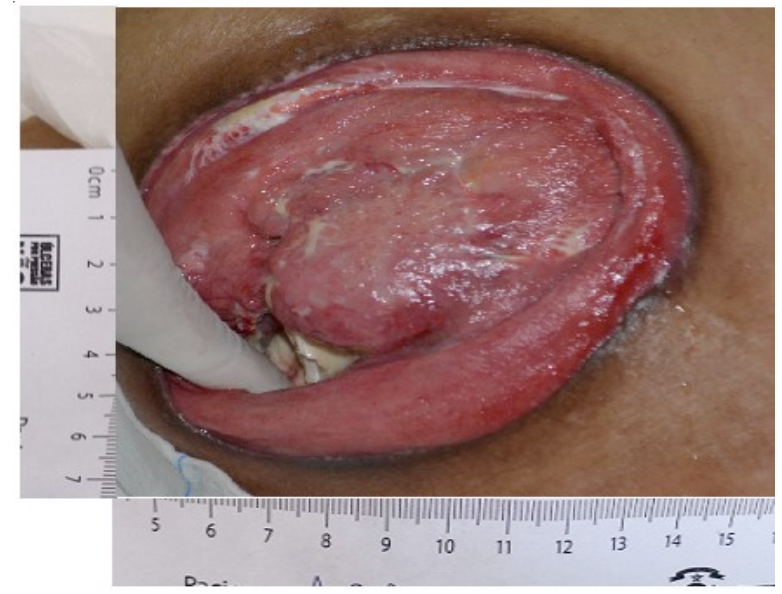

Figura 09B: Região do trocanter Direito, após 15 dias de tratamento

Após 15 dias de tratamento houve uma melhora significativa em relação ao tecido presente, com praticamente toda área coberta por tecido de granulação. Houve também uma regressão das bordas com diminuição da área da lesão $\left(39,7 \mathrm{~cm}^{2}\right)$, odor com score 5 , e secreção escassa durante a troca do curativo (FIGURA 9B). 


\section{DISCUSSÃO}

O estudo apresentou como limitações o restrito número de pacientes por amostra, por se tratar de pesquisa clínica experimental, com um grupo investigado altamente selecionado pelos critérios de exclusão e inclusão.

A incidência de LPP em pacientes hospitalizados nos EUA varia de $2 \%$ a $40 \%$ e de acordo com estudo realizado pelo The National Pressure Ulcer Advisory Panel (EUA), o custo estimado do tratamento para úlcera de pressão é de US\$2.000 a US $\$ 30.000$ por paciente, sendo o custo anual estimado em US\$ 8,5 bilhões. Apesar de poucas evidências científicas, a incidência e os custos de tratamento de LPP no Brasil acompanham os dados mundiais. Neste sentido, pesquisas clínicas como estas são muito importantes para o desenvolvimento e a experimentação de coberturas eficientes e de baixo custo no tratamento de LPP. Novas descobertas visam acelerar o tempo de cicatrização e melhorar a qualidade de vida do paciente, esse fato motivou a realização deste estudo (NEPUAP, 2014).

Observou-se em todos os pacientes, redução significativa do tecido inviável, principalmente no paciente 2 , em que a lesão se apresentava coberta por tecido necrosado e seco, e após o uso do curativo de hidrogel com NPAg por um período de 15 dias, houve o aparecimento de tecido de granulação, responsável pela epitelização da ferida. Os hidrogéis produzido pelo IPEN, são classificados como curativos primários e de excelência para hidratação e manutenção de um ambiente úmido por ser formado por cerca de $90 \%$ de água. Tem a propriedade de liberar para a ferida seca, a umidade necessária para realizar um debridamento autolitíco. Conforme Iron (2005), o debridamento autolitíco envolve o uso de curativos sintéticos para cobrir a ferida, e permitir a remoção do tecido desvitalizado por enzimas normalmente presentes nos fluidos da lesão.

Das 6 (seis) feridas estudadas, 3 (três), sendo dos pacientes $1^{\mathrm{B}}, 2$ e 4 , apresentaram um aumento da área lesionada. Isso ocorreu porque as feridas apresentavam grande quantidade de tecido inviável, e com o uso do hidrogel com NPAg houve um debridamento, aumentando a área da ferida. Em contrapartida, houve melhora do leito das feridas, revelando que o tamanho e o formato de uma ferida podem alterar durante o processo de cicatrização e/ou durante o tratamento. Blanes e Ferreira (2014) e Reis et al. (2012) referem que, apesar da redução da área lesada ser utilizada para julgar a evolução da ferida, em alguns, o aumento de sua 
extensão após desbridamento pode indicar a melhora da característica da lesão pela remoção do tecido desvitalizado. Algumas feridas podem parecer pequenas, entretanto, à medida que os tecidos necrosados e desvitalizados são removidos, a ferida parece aumentar de tamanho. Isso ocorre porque a real extensão da ferida estava mascarada por esses tecidos inviáveis.

Após o período de 15 dias em uso de hidrogel com NPAg nas LPPs, foi possível observar a diminuição do odor em todas as feridas da pesquisa, variável avaliada através da escala de TELER. Todas as feridas apresentavam odor fétido no início da pesquisa, que variou entre os scores 2 e 3 da escala, os quais refere odor na exposição da cobertura e próximo dela. O que pode estar relacionada à carga microbiana elevada nestes tipos de feridas crônicas, pois algumas bactérias são responsáveis pela liberação de ácidos voláteis, causadores do odor. Após o tratamento, as LPPs de todos os pacientes apresentaram melhora do odor, registrando resultados de 4 e 5 na escala TELER. Resultados semelhantes a este foram encontrados por outros autores que utilizaram a cobertura de hidrogel de quitosana com prata em feridas produzidas em ratos com bactérias multirresistentes. A fórmula mostrou-se eficaz, diminuindo o odor e a secreção na ferida (EL-NAGGAR et al, 2015).

As LPPs com alta carga microbiana podem beneficiar-se com a aplicação tópica de fármacos antibacterianas, como a prata. Atualmente algumas coberturas já incluem a prata em suas apresentações, como: Sivercel ${ }^{R}$, Aquacel $\mathrm{Ag}^{\mathrm{R}}$, Contreet $\mathrm{Ag}^{\mathrm{R}}$, entre outras. Conforme estudos de Bowler et al (2004); Vlachou et al. (2007), o mecanismo de liberação do íon da prata é complexo e lento, mas exerce efeito bacteriostático. Alguns estudos in vitro relatam sua atividade bactericida em cepas de microorganismos resistentes a antibióticos, dentre os quais: Staphylococcus aureus multiresistente, Pseudomonas aeruginosa e Candida albicans. Os efeitos antimicrobianos da prata nanocristalina resultam da alteração do DNA microbiano ou do bloqueio na cadeia respiratória e obtenção energética.

Durante o teste para avaliar o tipo de microorganismo presente nas lesões, realizado através da coleta de secreção por swab, foram evidenciados 4 tipos de bactérias, sendo elas: Pseudomonas aeroginosa, Klebsiella pneumoniae, Acinetobacter baumannii e Staphylococcus aureus. Estudos semelhantes registraram a presença de Staphylococcus aureus, Streptococcus sp, Pseudomonas mirabilis, Escherichia coli, P. Seroginosa, Klebsiella sp, e anaeróbios como B. fragilis 
em LPP, advertindo que Gram negativos, Gram positivos e anaeróbios são os microorganismos que mais prevalecem em LPP. A presença de Pseudomonas aeroginosa tem sido associada à rápida deterioração dos tecidos em LPP (MARTINS et al. 2010). A identificação da microbiota prevalente nas LPPs contribuiu para orientar a terapêutica e acompanhar a evolução dos ferimentos.

Analisando os resultados da variável dor, foi possível observar a diminuição em todos os pacientes, por meio da comparação dos registros na EVA entre o curativo utilizado anteriormente e o hidrogel NPAg. A média de dor relatado pelos pacientes no início da pesquisa variou entre moderada a intensa, na EVA, considerada dor intensa, e ao final da pesquisa a média da dor relatada por eles foi de uma mediana de 3 e 4 na EVA, considerado dor leve. O hidrogel testado apresentou ser uma boa opção de cobertura primária, por ser composto por aproximadamente $90 \%$ de água, não permitindo a aderência ao leito da ferida, protegendo as terminações nervosas. Pacientes com lesão medular ou com sequelas de AVE não foram incluídos nesta variável por apresentarem sensibilidade ausente ou diminuída na área estudada. De acordo com Upton e Andrews (2014), uma das vantagens dos curativos de hidrogéis é que eles protegem as terminações nervosas reduzindo assim a dor nos pacientes, causando menos desconforto durante as trocas, corroborando assim, o resultado da pesquisa.

O aumento da carga microbiana e a presença de tecidos inviáveis no processo de cicatrização tem como resultado a produção de exsudato purulento. $O$ tecido fibrinoso e o exsudato são indicadores de inflamação na ferida e o reparo não começará até que a causa do processo inflamatório seja controlada. As LPPs, por serem feridas crônicas, apresentam alta carga microbiana, e para controlar este processo, uma das alternativas é o uso de curativos antimicrobianos. Apesar do hidrogel com NPAg, não ser um curativo com grande poder de absorção, ele mostrou-se efetivo por remover o tecido desvitalizado em todos os casos apresentados e favorecer a proliferação do tecido de reparo, diminuindo assim a carga microbiana da ferida e consequentemente o exsudato.

Nos casos $1^{\mathrm{A}}, 2,3$ e 4, a membrana de hidrogel permaneceu no leito da ferida por 72 horas, sendo trocado apenas o curativo secundário. Corroborando os resultados de outros estudos em que o hidrogel com nanopartículas de prata apresenta liberação otimizada de prata por um período de 3 (três) dias, retardando a 
proliferação de microorganismos e diminuindo a produção de exsudato (BOOKNAW 2013).

Brown-Etris et al (2008) relatam que, a exsudação abundante, normalmente indicam um prolongado estágio inflamatório ou infecção, e que a presença de tecidos desvitalizados no leito da lesão prejudica a regeneração do tecido saudável. Estudos feitos por Paladini et al (2013) e Thomas (2008), apresentam resultados semelhantes a este estudo, quando se referem que, a combinação das propriedades antibacterianas e as físico-químicas do hidrogel com prata aceleram no processo de cicatrização e reduzem a carga microbiana das feridas, satisfazendo as exigências de coberturas clinicamente eficazes.

Uma preocupação na aplicação de curativos impregnados com NPAg, é seu efeito citotóxico em tecidos vivos. Os estudos de Monteiro et al (2009) e Wang et al. (2014) mostraram que, testes de citotoxidade de diferentes tipos de hidrogéis impregnados com NPAg, não apresentaram efeito negativo para as células, pois a liberação da prata depende da natureza de concentração do metal. Os testes de citotoxidade das membranas com NPAg do IPEN, foram realizados, e parecem demonstrar que não há ação citotóxica sobre os tecidos. Os resultados destes testes ainda não foram publicados pelos pesquisadores, necessitando de maior comprovação experimental.

O grande benefício observado neste estudo foi que, o hidrogel produzido pelo IPEN, apresenta um custo reduzido e as mesmas vantagens dos hidrogéis comercializados. O Brasil deve rever a sua política, fortalecendo a articulação entre ciências básicas e desenvolvimento de produtos, transcendendo o espaço estritamente acadêmico. Assim, conseguiremos agregar valores aos produtos nacionais e reduzir o quadro de dependência e defasagem tecnológica que afeta gravemente o SUS. Neste sentido, sugere-se a realização de outros estudos clínicos controlados para comprovar a aplicabilidade dos curativos de hidrogel com nanopartículas de prata no tratamento de lesões por pressão.

O tratamento com a membrana de hidrogel com NPAg, desenvolvido pelo IPEN, mostrou-se eficiente em todos os pacientes testados, devido à sua vantagem de manter o meio da lesão úmido, facilitando as enzimas intrínsecas do corpo a quebrarem o tecido inviável, proporcionando a regeneração celular. Isto foi observado a partir da mensuração das variáveis de quantidade de tecido desvitalizado, tamanho, dor, odor e quantidade de exsudato na ferida. 


\section{CONSIDERAÇÕES FINAIS}

Os hidogéis com NPAg, produzidos pelo IPEN, mostraram-se eficazes no tratamento das LPP, pois proporcionaram à ferida condições para a epitelização. Houve a diminuição do odor, dos tecidos desvitalizados e da dor, que quando presentes, retardam a cicatrização. Porém são necessários novos estudos, envolvendo estes curativos com um número maior de pacientes. 


\section{REFERÊNCIAS}

ADHYA, A. et al. Healing of burn wounds by topical treatment: A randomized controlled comparison between silver sulfadiazine and nano-crystalline silver. J Basic Clin Pharm, v. 6, n. 1, p.29-34, dez. 2014. doi: 10.4103/0976-0105.145776.

ALMEIDA, C.E. et al. Manual para realização de curativos. Rio de Janeiro: Cultura Médica, 2002.

AMMONS, M. C. B; WARD, L. S; A JAMES, G. Anti-biofilm efficacy of a lactoferrin/xylitol wound hydrogel used in combination with silver wound dressings. International Wound Journal, [s.I.], v. 8, n. 3, p.268-273, 1 abr. 2011. Wiley-Blackwell. http://dx.doi.org/10.1111/j.1742-481x.2011.00781.x.

BANAMER, S. et al. Synthesis and Characterization of hydrogels based on Poly (vinyl pyrrolidone), Nucl. Instr. And Meth. Phys. Res., B, v. 248, p. 284-290, 2006.

BELONI, J. Nucleatio, growth and properties of nanoclusters studies by radiation chemistry Application to catalysis. Catalysis Today, v. 113, p. 141-156, 2006

BERLOWITZ, D.; BERMAN, R.S.; SCHMADER, K. E. Treatment of pressure ulcers. Last literature review version 19, Jan 2011. Disponível em: <http://www.LPtodate.com/contents/treatment-of-pressure-ulcers> Acesso em: 23/04/2011.

BHOWMICK, S.; KOUL, V. Assessment of PVA/silver nanocomposite hydrogel patch as antimicrobial dressing scaffold: Synthesis, characterization and biological evaluation. Materials Science And Engineering: C, [s.I.], v. 59, n. 1, p.109-119, fev. 2016. Elsevier BV. http://dx.doi.org/10.1016/j.msec.2015.10.003.

BLACK, J. et al. An overview of tissue types in pressure ulcers: a consensus panel recommendation. Ostomy Wound Manage. v. 56, n. 4, p. 28-44, Apr 1. 2010.

BLANES, L. et al. Avaliação clínica e epidemiológica das úlceras por pressão em pacientes internados no Hospital São Paulo. Rev Assoc Med Bras, v. 50, n. 2, p. 182-7, 2004.

BLANES, L; FERREIRA, LM. Prevenção e tratamento de úlcera por pressão. São Paulo: Editora Atheneu. 2014 
BOONKAW, B. et al. Antimicrobial efficacy of a novel silver hydrogel dressing compared to two common silver burn wound dressings: Acticoat ${ }^{\mathrm{TM}}$ and PolyMem Silver® Burns. 2013.

BORGES, E. L. Feridas: Lesões dos membros inferiores. Rio de Janeiro: Guanabara. 2012. v. 1, p. 203.

BOSANQUET, D. C. et al. A review of the surgical management of heel pressure ulcers in the 21st century. International Wound Journal, [s.I.], v. 13, n. 1, p.9-16, 16 fev. 2015. Wiley-Blackwell. http://dx.doi.org/10.1111/iwj.12416.

BOWLER, P. G. et al. Microbicidal properties of a silver- containing hydrofiber dressing against a variety of burn wound pathogens. J. Burn Care Rehabil., 2004.

BROWN, A. Phases of the wound healing process. Nurs Times, v. 111, n. 46, p. 123, nov. 2015.

BROWN-ETRIS et al. A prospective, randomized, multisite clinical evaluation of a transparent absorbent acrylic dressing and a hydrocolloid dressing in the management of stage II and shallow stage III pressure ulcers. Adv Skin Wound Care, 2008.

BROWNE, N. et al. The teller system in wound care research and post market surveillance. EWMA Journal, 2004.

BRYANT, R. A.; NIX, D. P. Acute \& Chronic wound: Current management concepts. Mosby: Elsevier, 2007.

CASTRO, D. L. V.; SANTOS, V. L. C. G. Controle do odor de feridas com metronidazol: revisão sistemática. Rev Esc Enferm USP, v. 49, n. 5, p. 858-863, 2015.

CHACON, J. M. F. et al. Prevalence of pressure ulcers among the elderly living in long-stay institutions in São Paulo. Sao Paulo Med. J., Jul. 2009.

CHAKAVALA, Sr et al. Development and in vivo evaluation of silver sulfadiazine loaded hydrogel consisting polyvinyl alcohol and chitosan for severe burns. Journal Of Pharmacy And Bioallied Sciences, [s.I.], v. 4, n. 5, p.54-56, mar. 2012. Medknow. http://dx.doi.org/10.4103/0975-7406.94131. 
COLEMAN, S. et al. A new pressure ulcer conceptual framework. Journal of Advanced Nursing, v. 70, n. 10, p. 2222-2234, 2014.

COSTA, M. P. et al. Epidemiologia e tratamento das úlceras de pressão: experiência de 77 casos. Acta Ortop. Bras., Santa Cecília, v. 13, n. 3, p. 124-133, 2005.

DEALEY, C. Cuidando de feridas: um guia para as enfermeiras. 3. ed. São Paulo: Editora Atheneu, 2008.

DICCINI S et al. Incidência de úlcera de pressão em pacientes neurocirúrgicos de hospital universitário. Acta Paul Enferm., v. 22, n. 2, p. 205-9, 2009.

EL-NAGGAR, Moustafa Y. et al. Hydrogel Dressing with a Nano-Formula against Methicillin-Resistant Staphylococcus aureus and Pseudomonas aeruginosa Diabetic Foot Bacteria. Journal Of Microbiology And Biotechnology, [s.I.], v. 26, n. 2, p.408-420, 24 nov. 2015.

ESTEBAN-VIVES, Roger et al. Effects of wound dressings on cultured primary keratinocytes. Burns, [s.I.], v. 42, n. 1, p.81-90, fev. 2016. Elsevier BV. http://dx.doi.org/10.1016/j.burns.2015.06.016.

FALABELLA, A. F. Debridement and wound bed preparation. Dermatologic Therapy. v. 19, p. 317-325, 2006.

FÁZIO, M. J.; ZITELLI, J. A.; GOSLEN, J. B. Cicatrização de Feridas. In: Coleman III, W. P., Hank, C., Alt, T. H., Asken, S. Cirurgia Cosmética - Princípios e Técnica. $2^{a}$ ed. Rio de Janeiro: Revinter, 2010.

FERNANDES, N. C. S, TORRES, G. V. Incidência e fatores de risco de úlceras de pressão em pacientes de unidade de terapia intensiva. Ciênc Cuid Saúde, v. 7, n. 3, p. 304-10, 2008.

FLETCHER, R. H.; FLETCHER, S. W.; Epidemiologia Clínica: elementos essenciais. 4. ed. Porto Alegre: Artmed, 2006.

FRANCO, D.; GONÇALVES, L. F. Feridas cutâneas: a escolha do curativo adequado. Rev. Col. Bras. Cir., Rio de Janeiro, v. 35, n. 3, p. 203-206, 2008. 
FREEMAN, K. et al. Pain measurement scales: a comparison of the visual analogue and faces rating scales in measuring pressure ulcer pain. $\mathbf{J}$ Wound Ostomy Continence Nurs, v. 28, n. 6, p. 290-6, nov. 2001.

GALLI, M. M.; PROTZMAN, N. M.; BRIGIDO, S. A.. Utilization of Silver Hydrogel Sheet Dressing on Postsurgical Incisions: A Pilot Study in Foot and Ankle Surgery. Foot \& Ankle Specialist, [s.I.], v. 6, n. 6, p.422-433, 23 out. 2013. SAGE Publications. http://dx.doi.org/10.1177/1938640013507108.

GIRARDI, R. C. G. Comportamento de matrizes de colágeno utilizadas no tratamento de feridas planas induzidas em pele de rato. 2005. 101 p. Dissertação (Mestrado). Universidade de São Paulo, São Carlos.

GONCALVES, G. P. et al. Avaliação da qualidade dos ensaios clínicos aleatórios em terapia intensiva. Rev. bras. ter. Intensive, v. 21, 2009.

Grupo Nacional para el Estudio Y Asesorameinto en Lesões por presión Y Heridas Crônicas (GNEALPP). Comisiones de lesões por presión. Documento Técnico $n^{0}$ 1. Logroño: GNEALPP, 2012.

IRION, G. Feridas: Novas abordagens, manejo clínico e atlas em cores. Rio de Janeiro: Guanabara Koogan, 2005.

JONES, A.; VAUGHAN, D. Hydrogel dressings in the management of a variety of wound types: A review. Journal of Orthopaedic Nursing, v.9, pp. SI- S11, 2005.

JOVANOVIC, Z. et al. Structural andoptical characteristics of silver/poly (N-Vinyl-2pyrrolidone) nanosytems synthesized by y-iradiation. Radiat. Sci. A. Polym. Chem., v. 81, n. 11, p. 1720-1728, 2012.

KHAMPIENG, T.; BRIKSHAVANA, P.; SLPAPHOL, P. Silver nanoparticle-embedded poly(vinyl pyrrolidone) hydrogel dressing: gamma-ray synthesis and biological evaluation. Journal Of Biomaterials Science, Polymer Edition, [s.I.], v. 25, n. 8, p.826-842, 23 abr. 2014. Informa UK Limited. http://dx.doi.org/10.1080/09205063.2014.910154.

LIMA, A. C., GUERRA, D. M. Avaliação do custo do tratamento de lesões por pressão em pacientes hospitalizados usando curativos industrializados. Rev. Ciências \&Saúde Coletiva, v. 16, n. 1, p. 267-277, 2011. 
LISBOA, C.R. Risco para úlcera por pressão em idosos institucionalizados. 2010. 148 f. Dissertação (Mestrado) - Universidade Federal de Minas Gerais, Escola de Enfermagem, Belo Horizonte, 2010.

LO, S. F. et al. A systematic review of silver-releasing dressing in the management of infected chronic wounds. J. Clin. Nurs, v. 17, p.1973-1985, 2008.

LUGÃO, A. B. et al. Study of wound dressing structure and hydration/dehydration properties, Radiat. Phys. Chem., v. 52, n. 1-6, p. 319-322, 1998.

LUGÃO, A. B.; MALMONGE, S. M. Use of radiation in the production of hydrogels. Nucl. Instrum. Meth. Phys. Res., v. 185, p. 37-42, 2001.

LLPERGOLO, L. C.; LUGÃO, A. B.; CATALANI, L H. Development of a poly (N-vynil2-pyrrolidone)/ poly(ethylene glycol) hydrogel membrane reinforced with methyl methacrylate-grafted polypropylene fibers for possible use as wound dressing. J. Appl. Pol. Sc., v.86, p. 662-666, 2002.

MAIDA, V. et al. Symptoms Associated with Malignant Wounds: A Prospective Case Series. Journal of Pain and Symptom Management. v. 37, n. 2, p. 206-211. 2009.

MALAGUTTI, W. (organizador) Feridas: conceitos e atualidades. São Paulo: Ed Martinari, 2015.

MARTINS, P.A.E. Avaliação de três técnicas de limpeza do sítio cirúrgico infectado utilizando soro fisiológico para remoção de microrganismos. Rev. Ciências de Cuidados à Saúde, 2012.

MATSUZAKI, K.; KISHI, K.. Investigating the pressure-reducing effect of wound dressings. Journal Of Wound Care, [s.I.], v. 24, n. 11, p.512-517, 2 nov. 2015. Mark Allen GroLP. http://dx.doi.org/10.12968/jowc.2015.24.11.512.

MEIRELES, I. B.; SILVA, R. C. L. DA. Fundamentos biológicos para o atendimento aos portadores de lesões de pele. In: Silva, R.C.L. da. Feridas: Fundamentos e atualizações em enfermagem. $3^{\mathrm{a}}$ ed. São Caetano do Sul: Yedis, 2011.

BRASIL. Ministério da Saúde. Secretaria de Políticas de Saúde. Departamento de Atenção Básica. Manual de condutas lesões neutróficas e traumáticas. Ministério da Saúde; 2009. Brasília. 
MONTEIRO, D. R. et al. The growing importance of materials that prevent microbial adhesion: antimicrobial effect of medical devices containing silver. Int. J. Antimicr. Agents, v. 34, p. 103-110, 2009.

MORISON, M., et al. Prevenção e tratamento de úlceras de pressão, ISBN 9728383-68-1, Lusociência, Loures, 2004.

NEIBERT, K. et al. Wound-Healing with Mechanically Robust and Biodegradable Hydrogel Fibers Loaded with Silver Nanoparticles. Advanced Healthcare Materials, [s.I.], v. 1, n. 5, p.621-630, 12 jul. 2012. Wiley-Blackwell. http://dx.doi.org/10.1002/adhm.201200075.

NEPUAP. EUROPEAN PRESSURE ULCER ADVISORY PANEL; NATIONAL PRESSURE ULCER ADVISORY PANEL. Treatment of pressure ulcers: Quick Reference Guide. Washington DC: National Pressure Ulcer Advisory Panel, 2014.

NEPUAP. EUROPEAN PRESSURE ULCER ADVISORY PANEL; NATIONAL PRESSURE ULCER ADVISORY PANEL. Treatment of pressure ulcers: Quick Reference Guide. Washington DC: National Pressure Ulcer Advisory Panel, 2016.

NOWACK, B.; KRUG, H. F.; HEIGHT, M. 120 years of nanosilver history: implications for policy makers. Eviron. Sci. Technol., v. 45, p. 1177-1183, 2011.

OLIVEIRA, R. N. et al. Mechanical properties and in vitro characterization of polyvinyl alcohol-nano-silver hydrogel wound dressings. Interface Focus, [s.l.], v. 4, n. 1, fev. 2014. The Royal Society. http://dx.doi.org/10.1098/rsfs.2013.0049.

OLIVEIRA, B. G. R. B.; CASTRO, J. B. A., ANDRADE, N. C., Técnicas utilizadas na aferição de feridas e avaliação do processo cicatricial. Saúde Coletiva, v. 2, n. 6, 2005.

OYARZUN-AMPUERO, F. et al. Nanoparticles for the Treatment of Wounds. Curr Pharm Des. v. 21, n. 29, p. 4329-41, 2015.

PAGGIARO, A. O.; TEIXEIRA, N. N.; FERREIRA, M. C. Princípios gerais do tratamento de feridas. Revista de Medicina, v. 89, n. 3/4, p. 132-136, dez. 2010. ISSN 1679-9836. 
PALADINI, F. et al. Silver-doped self-assembling di-phenylalanine hydrogels as wound dressing biomaterials. J Mater Sci: Mater Med, [s.I.], v. 24, n. 10, p.24612472, 21 jun. 2013. Springer Science + Business Media. http://dx.doi.org/10.1007/s10856-013-4986-2.

PALFREYMAN, S.J.; STONE, P. W. A systematic review of economic evaluations assessing interventions aimed at preventing or treating pressure ulcers. International Journal Of Nursing Studies, [s.I.], v. 52, n. 3, p.769-788, mar. 2015. Elsevier BV. http://dx.doi.org/10.1016/j.jjnurstu.2014.06.004..

PARK, M. et al. Effect of discarded keratin-based biocomposite hydrogels on the wound healing process in vivo. Materials Science And Engineering: C, [s.I.], v. 55, p.88-94, out. 2015. Elsevier BV. http://dx.doi.org/10.1016/j.msec.2015.03.033.

PATEL, A.; MEQUANINT, K. Hydrogel Biomaterial. In: Biomedical Engieneering Frontiers and Challenges, Fazel-Razai, R. (ed), InTech, cap. 14, 2011.

PAULA, F. T. O.; BRUNA, S. F. T.; MARLENE, A. M.; ANACLARA, F. V. T.; LÍLIAN, V. P. Avaliação da dor durante a troca de curativo de úlceras de perna. Texto Contexto Enferm, v. 21, n. 4, p. 862-9, Florianópolis, out-dez, 2012.

PERCIVAL, S. I.; SULEMAN, L. Slough and biofilm: removal of barriers to wound healing by desloughing. Journal Of Wound Care, [s.I.], v. 24, n. 11, p.498-510, 2 nov. 2015. Mark Allen GroLP. http://dx.doi.org/10.12968/jowc.2015.24.11.498.

REIS, C. L. D. et al. Mensuração de área de lesões por pressão por meio dos softwares Motic e do AutoCAD ${ }^{\circledR}$. Rev. bras. enferm, v. 65, n. 2, p. 304-308, 2012.

RENNER, Regina; SIMON, Jan C.; TREUDLER, Regina. Contact Sensitization to Modern Wound Dressings in 70 Patients With Chronic Leg Ulcers. Dermatitis, [s.I.], v. 24, n. 2, p.60-63, 2013. Ovid Technologies (Wolters Kluwer Health). http://dx.doi.org/10.1097/der.0b013e318284d9f2.

ROGENSKI, N. M. B.; SANTOS, V. L. C. G. Estudo sobre incidência de lesões por pressão em um hospital universitário. Lat. Am. Enferm. v. 13, n. 4, p. 474-80, 2005.

ROSIAK, J. M.; RUCINSKA-REYBAS, A.; PEKALA, W. Method of manufacturing of hydrogels dressing. U.S. PATENT, v. 4, n. 871, p. 490, 3 Out., 1989.

ROSIAK, J. M.; ULANSKI, P. Synthesis of hydrogels by irradiation of polymers in 
aqueous solution. Radiat. Phys. Chem., v. 55, p. 139-151, 1999.

ROWLEY-CONWY G. Infection prevention and treatment in patients with major burn injuries. Nurs Stand, v. 25, n. 7, p. 51-2, 2010.

SACCO, Pasquale et al. Silver-containing antimicrobial membrane based on chitosan-TPP hydrogel for the treatment of wounds. J Mater Sci: Mater Med, [s.I.], v. 26, n. 3, p.128-128, 19 fev. 2015. Springer Science + Business Media. http://dx.doi.org/10.1007/s10856-015-5474-7.

SALES, M. C. M.; BORGES, E. L.; DONOSO, M. T. V. Risco e prevalência de lesões por pressão em uma unidade de internação de um hospital universitário de Belo Horizonte. REME Rev Min Enferm. v. 14, n. 4, p. 566-75, 2010.

SAMBERG, M. E. et al. Silver nanoparticles do not influence stem cell differentiantion but cause minimal toxicity. Nanomedicine, v. 7, n. 8, p. 1197-1209, 2012.

SANTOS, V. L. C. G. et al. Adaptação Transcultural do Pressure Ulcer Scale for Healing (PUSH), para a língua portuguesa. Rev. latinoam. enferm. v. 13, n. 3, p. 13305, mai-jun., 2005.

SARABAHI S. Recent advances in topical wound care. Indian J Plast Surg. v. 45, n. 2, p.379-87, 2012.

SHIN HS et al. Mechanism of growth of colloidal silver nanoparticles stabilized by polyvinyl pyrrolidone in y - irradiated silver nitrate solution. J. Coll. Interf. Sci., v. 274, p. 89-94, 2004.

SIBBALD, R. G.; ORSTED, H. L.; COUTTIS, P. M.; KEAST, D. H. Best practice recommendations for preparing the wound bed: LPdate 2006. Wound Care Canada. v. 4, n. 1, 2006.

SINGH, D.; SINGH, A.; SINGH, R. Polyvinyl pyrrolidone/carrageenan blend hydrogels with nanosilver prepared by gamma radiation for use as an antimicrobial wound dressing. Journal Of Biomaterials Science, Polymer Edition, [s.I.], v. 26, n. 17, p.1269-1285, 23 set. 2015. Informa UK Limited. http://dx.doi.org/10.1080/09205063.2015.1087366.

SINGH, R., SINGH, D. Radiation synthesis of PVP/alginate hydrogel containing nanosilver as wound dressing. J Mater Sci Mater Med. v. 23, n. 11, nov., 2012. 
SOLEY, Bruna da Silva et al. Kinin receptors in skin wound healing. Journal Of Dermatological Science, [s.I.], v. 82, n. 2, p.95-105, maio 2016. Elsevier BV. http://dx.doi.org/10.1016/j.jdermsci.2016.01.007.

SPETZ, J., BROWN, D. S., AYDIN, C., DONALDSON, N. The value of reducing hospital acquired pressure ulcer prevalence: an illustrative analysis. J Nurs Adm. v. 43, n. 4, p. 235-41, abr., 2013.

SUNARTI, S. Successful Treatment of Unstageable Pressure Ulcer by Using Advanced Wound Dressing. Acta Med Indones, v. 47, n. 3, p. 251-2, jul., 2015.

THOMAS, R. Acoustic pressure wound therapy in the treatment of stage II pressure ulcers. Ostomy Wound Manage, v. 54, n. 11, p. 56-8, nov., 2008.

TURNER, T. D. Semiocclusive and occlusive dressings. In: RYAN, T. An environment for healing: the role of occlusion. London: Royal Society of Medicine, 1984 (Royal Society of Medicine International Congress and Symposium Series, 88).

UPTON, D1, ANDREWS, A2. The impact of stress at dressing change in patients with burns: a review of the literature on pain and itching. Wounds. v. 26, n. 3, p. 7782, mar., 2014.

VLACHOU, E. et al. The safety of nanocrystalline silver dressings on burns: a study of systemic silver absorption. Burns. v. 33, n. 8, p. 979-85, 2007.

WALKER, R.; AITKEN, L. Pressure injury prevention pilot study: a follow-LP. QId Nurse. v. 34, n. 3, p. 33, jun., 2015.

WANG, Chan et al. A nano-silver composite based on the ion-exchange response for the intelligent antibacterial applications.Materials Science And Engineering: C, [s.I.], v. 41, n. 1, p.134-141, ago. 2014. Elsevier BV. http://dx.doi.org/10.1016/j.msec.2014.04.044.

WANG, M., et al. "Radiation synthesis of PVP/CMC hydrogels as wound dressing", Nuclear Instruments and Methods in Physics Research B., v. 265, p. 385-389, set., 2007. 
Database Of Systematic Reviews, 28 mar. 2013. Wiley-Blackwell. http://dx.doi.org/10.1002/14651858.cd002106.pub4.

WAYCASTER, C.; MILNE, C. T. Clinical and economic benefit of enzymatic debridement of pressure ulcers compared to autolytic debridement with a hydrogel dressing. J Med Econ. v. 16, n. 7, p. 976-86, jul., 2013.

WHO - World Health Statistics. Snapshtof global health. World Health Organization 2012. Disponível em http://www.who.int/gho. Acesso em 16/07/2013.

WOUND, OSTOMY AND CONTINENCE NURSES SOCIETY - WOCN. Guideline for prevention and management of pressure ulcers. Glenview, p. 52, 2003.

WU, JIAN et al. Antimicrobial Properties of Nanostructured Hydrogel Webs Containing Silver. Biomacromolecules, [s.I.], v. 10, n. 9, p.2686-2693, 14 set. 2009. American Chemical Society (ACS). http://dx.doi.org/10.1021/bm900620w. 


\section{APÊNDICE 1}

\section{TERMO DE CONSENTIMENTO LIVRE E ESCLARECIDO}

Você está sendo convidado (a) como voluntário (a) a participar da pesquisa: APLICABILIDADE DE CURATIVOS A BASE DE HIDROGEL COM NANOPARTÍCULAS DE PRATA EM LESÃO POR PRESSÃO. A JUSTIFICATIVA, OS OBJETIVOS E OS PROCEDIMENTOS: No Brasil, as feridas constituem um sério problema de saúde pública, devido ao grande número de doentes com alterações na integridade da pele, embora sejam escassos os registros desses atendimentos o elevado número de pessoas com lesões contribui para onerar o gasto público, além de interferir na qualidade de vida da população. Este estudo ocorrerá no Hospital Regional Público de Porto Nacional no período de 30 meses. No inicio da pesquisa será realizada uma coleta de dados a respeito do paciente para avaliação das condições atuais do mesmo, sendo esta avaliação refeita a cada 7 dias durante as 3 semanas de experimentação. Este estudo visa avaliar a serventia da nanopartícula de prata nas formas de solução líquida e membranas de hidrogel no tratamento clínico de lesões por pressão e pé diabético em usuários do SUS. Trata-se de uma pesquisa experimental, aleatória, para selecionar pacientes com lesões de pressão e pé diabético onde serão utilizados dois tipos de curativos, sendo um dos tratamentos a base de hidrogel com nanoprata e o outro tratamento com gazes úmidas com solução salina.

DESCONFORTOS E RISCOS E BENEFÍCIOS: em hipótese alguma os pesquisadores divulgarão os nomes do participante e os mesmos não serão submetidos a desconfortos, podendo desistir da pesquisa a qualquer momento se assim desejar ou deixar de responder as perguntas que julgar impróprias ou que the causem constrangimento de qualquer natureza.

FORMA DE ACOMPANHAMENTO E ASSINTÊNCIA: Caso você apresente algum problema durante os curativos, em seus exames clínico, preventivos ou de rotina, você será acompanhado (a) e encaminhado (a) para tratamento adequado ao tipo de doença da seguinte maneira: será acompanhado pela equipe médica do Hospital Regional Público de Porto Nacional.

GARANTIA DE ESCLARECIMENTO, LIBERDADE DE RECUSA E GARANTIA DE SIGILO: Você será esclarecido (a) sobre a pesquisa em qualquer aspecto que desejar. Você é livre para recusar-se a participar, retirar seu consentimento ou interromper a participação a qualquer momento. A sua participação é voluntária e a recusa em participar não irá acarretar qualquer penalidade ou perda de benefícios. Os pesquisadores irão tratar a sua identidade com padrões profissionais de sigilo. Os resultados da pesquisa serão para fins de projeto de extensão. Seu nome ou o material que indique a sua participação não será liberado sem a sua permissão. Você não será identificado (a) em nenhuma publicação que possa resultar deste estudo. Uma cópia deste consentimento informado será arquivada com as pesquisadoras e outra será fornecida a você.

CUSTOS DA PARTICIPAÇÃO, RESSARCIMENTO E INDENIZAÇÃO POR EVENTUAIS DANOS: A participação no estudo não acarretará custos para você e não será disponível nenhuma compensação financeira adicional.

DECLARAÇÃO DO PARTICIPANTE 
$\mathrm{Eu}$, (paciente) fui informado (a) dos objetivos da pesquisa acima de maneira clara e detalhada e esclareci minhas dúvidas. Sei que em qualquer momento poderei solicitar novas informações e motivar minha decisão se assim o desejar. O professor coordenador Aparecido Osdimir Bertolin e/ou as pesquisadoras certificou-me de que todos os dados deste estudo serão para fins de pesquisa.

Também sabemos que caso existam gastos adicionais, estes serão absorvidos pelo orçamento da pesquisa. Em caso de dúvidas poderemos chamar a pesquisadora Talita Rocha Cardoso nos telefones (63) 84879491. Declaro que concordo em participar desse estudo. Recebi uma cópia deste termo de consentimento livre e esclarecido e me foi dado (a) oportunidade de ler e esclarecer todas as dúvidas.

Nome Assinatura do Participante Data

Nome Assinatura do Pesquisador Data

Nome Assinatura do Pesquisador Data

\begin{tabular}{lll}
\hline Nome & Assinatura da Testemunha
\end{tabular}


ANEXO A

CEP - COMITÊ DE ÉTICA EM PESQUISA COM SERES HUMANOS

Universidade Federal do Tocantins

\begin{tabular}{|l|c|}
\hline \multicolumn{1}{|c|}{ PARECER CONSUBSTANCIADO } & \\
\hline PROJETO DE PESQUISA OU TIPO DE TRABALHO: Projeto de & PROCESSO No \\
pesquisa clínica dos pesquisadores Talita Cardoso, Albeliggia & \\
Vicentine e Ademar Lugão sob coordenação do Dr. Aparecido \\
Bertolin.
\end{tabular}

O parecer consubstanciado do relator será utilizado como subsídio para o Comitê de Ética em Pesquisa da Fundação Universidade do Tocantins elaborar seu parecer final.

1 - Identificação da Proposta de Projeto de Pesquisa/Trabalho de Conclusão de Curso Título: ESTUDOS CLÍNICOS PARA O DESENVOLVIMENTO DE CURATIVOS AVANÇADOS DE BAIXO CUSTO A BASE DE HIDROGÉIS DE NANOPRATA E PAPAÍNA.

Coordenador do Projeto: Prof. Doutor Aparecido Osdimir Bertolin.

Pesquisadores: Talita Cardoso, Albeliggia Vicentine e Ademar Lugão

Curso/ Departamento/Faculdade: Instituto Tocantinense Presidente Antonio Carlos e Instituto de Pesquisas Energéticas e Nucleares

2 - Análise do Projeto de Pesquisa/Trabalho de Conclusão de Curso

1. Os autores do projeto anexaram os seguintes documentos à sua avaliação por este CEP.

a. Folha de Rosto para pesquisas envolvendo seres humanos (CONEP);

b. Declaração da instituição proponente (ITPAC);

c. Declaração de autorização (Hospital Regional Público de Porto Nacional);

d. Declaração do responsável pela pesquisa de que a pesquisa se encontra em fase inicial;

e. Termo de consentimento livre e esclarecido;

f. Declaração do participante;

g. Termo de consentimento livre e esclarecido - familiar;

h. Declaração do familiar;

i. Cronograma;

j. Orçamento de projeto de pesquisa;

k. Instrumento de pesquisa;

I. Currículos Lattes dos participantes do Projeto de pesquisa;

m. Cópia impressa do Projeto de pesquisa;

n. Termo de autorização para registro fotográfico;

o. Tabela de avaliação de custos..

2. Na análise dos documentos foi verificado que estão adequadamente preenchidos e assinados.

3. O projeto apresenta boa fundamentação teórica.

4. O cronograma de execução da pesquisa está descrito em ordem numeral, contando 36 meses. 
2.1 - Objetivos e Adequação metodológica (Verificar a exeqüibilidade da proposta, isto é, se existe clareza do objeto, compatibilidade entre os objetivos, a fundamentação teórica e a metodologia ou plano de ação, evidenciando consistência entre objetivos, procedimentos, ações de execução da pesquisa e capacidade do proponente, demonstrada por outros trabalhos similares.)

1. O objetivo geral e os objetivos específicos do projeto são claros e possuem relação entre si.

2. O projeto apresenta ampla e concisa descrição dos instrumentos propostos para coleta de dados.

\section{2 - Avaliação do Questionário a ser aplicado e do Termo de Consentimento Livre e}

Esclarecido

1. O questionário para coleta de dados da pesquisa foi apresentado e o mesmo possui boa formatação.

2. O TCLE é bem redigido e apresenta os números de telefones de contato junto aos pesquisadores.

2.3 - Revisão Bibliográfica

A revisão bibliográfica é adequada e referencia de materiais científicos.

3 - Qualificação do Pesquisador/Orientador (Indicar os atributos do Pesquisador/Orientador, salientando a titulação e experiência compatível com a função de orientação; qualidade e regularidade da produção científica/tecnológica/artística, compatível com o projeto de pesquisa/Trabalho de Conclusão de Curso)

1. Segundo a base de dados do currículo Lattes, o Prof. Dr. Aparecido Osdimir Bertolin é graduado em Ciências Biomédicas e doutor em Microbiologia Aplicada. Diante do exposto, compreende-se que o referido professor possui totais condições para atuar como responsável pela pesquisa proposta.

4 - Parecer conclusivo, recomendações e/ou sugestões:

1. O projeto é bem redigido e apresenta referências técnico-científicas.

2. Na página 19 é descrito: "A prata foi demonstradA em estudos in vitro...". Sugiro a adequação da grafia da palavra demonstradA.

3. Na página 20 é descrito: "a) Infecções são mais facilmente debeladas, mesmo aquelas resistentes aos antibiótico de ultima geração, pois a prata não gera resistência de ultima geração, pois a prata não gera resistência". Sugere-se a adequação da concordância verbal do trecho "resistentes aos antibiótico".

4. Na página 21 é citado "Portanto, a busca de novos materiais é atualmente o objetivo de vários estudos (MEAUNE,et al., 2004)" Contudo o referido autor e obra não são apresentados nas REFERÊNCIAS. Sugere-se adequação, com a inclusão da obra científica no conjunto das referências do projeto.

5. Na página 29 è descrito: "b) Higienizar as mãos, conforme protocolo do Ministério da Saúde (2009), colocar a máscara e retirar o curativo anterior com luva de procedimento, avaliando quantidade". Contudo a referida obra não é apresentada nas REFERÊNCIAS. Sugere-se adequação, com a inclusão da obra científica no conjunto das referências do projeto.

6. Na página 31 é descrito: "O objetivo da avaliação é fornecer informações básicas sobre o estado da ferida, para que o seu processo possa ser monitorado assim como para assegurar que foi realizada uma seleção adequada dos produtos para seu tratamento (Keast, et al.,2004")". Contudo o referido autor e obra não são apresentados nas REFERÊNCIAS. Sugere-se adequação, com a inclusão da obra científica no conjunto das referências do projeto.

7. Na página 31 é descrito: "Por exemplo, uma ferida superficial com infecção é classificada como 2B (ADA, 2009)". Contudo a referida obra não é apresentada nas REFERÊNCIAS. Sugere-se adequação, com a inclusão da obra científica no conjunto 
das referências do projeto.

8. Na página 34 é feita citação de SINGH, SINGHT, 2012. Sugere-se a adequação da citação de acordo com o apresentado nas REFERÊNCIAS.

9. Na página 39 e feita referencia ao seguinte estudo: "BOONKAW B, KEMPF M, KIMBLE $R$, SUPAPHOL P. CUTTLE L. Antimicrobial efficacy of a novel silver hydrogel dressing compared to two common silver burn wound dressings:Acticoat ${ }^{\mathrm{TM}}$ and PolyMem Silver ${ }^{\circledR}$ Burns. 2013" Sugere-se ajustar a grafia do sobrenome do autor principal (Boonkaew B).

10. A bibliografia deve ser organizada de maneira uniforme. Assim sendo, solicita-se a utilização de apenas um formato para descrição dos autores referenciados.

5 - Pendências: (Enumerar sucintamente as pendências a serem sanadas pelo Coordenador do Projeto de Pesquisa/Trabalho de Conclusão de Curso)

1. Não apresenta pendências.

\section{6 - Parecer Consubstanciado}

\begin{tabular}{|c|c|c|}
\hline Aprovado: $\mathbf{X}$ & Não aprovado: & Aprovado e encaminhado para à CONEP. \\
\hline $\mathbf{7}$ - Dados do CEP-UFT
\end{tabular}

Nome Completo:

Comitê de Ética em Pesquisa com Seres Humanos

Telefone(s):

(63) 3232-8023

Local:

Palmas/TO

Instituição:

Instituição:
Universidade Federal do Tocantins
$\begin{aligned} & \text { Data: } \\ & \text { 11/09/2013 }\end{aligned}$
Data da reunião: 13/09//2013

Assinatura do Coordenador do CEP:

Data da reunião: 13/09//2013 